\title{
Dietary sugars and body weight: systematic review and meta-analyses of randomised controlled trials and cohort studies
}

\author{
(a) (1) $\Theta$ OPEN ACCESS
}

\author{
Lisa Te Morenga research fellow ${ }^{12}$, Simonette Mallard research assistant ${ }^{1}$, Jim Mann professor ${ }^{123}$
}

'Departments of Human Nutrition and Medicine, University of Otago, PO Box 56, Dunedin 9054, New Zealand ; ${ }^{2}$ Riddet Institute, University of Otago; ${ }^{3}$ Edgar National Centre for Diabetes and Obesity Research, University of Otago

\begin{abstract}
Objective To summarise evidence on the association between intake of dietary sugars and body weight in adults and children.

Design Systematic review and meta-analysis of randomised controlled trials and prospective cohort studies.

Data sources OVID Medline, Embase, PubMed, Cumulative Index to Nursing and Allied Health Literature, Scopus, and Web of Science (up to December 2011).

Review methods Eligible studies reported the intake of total sugars, intake of a component of total sugars, or intake of sugar containing foods or beverages; and at least one measure of body fatness. Minimum duration was two weeks for trials and one year for cohort studies. Trials of weight loss or confounded by additional medical or lifestyle interventions were excluded. Study selection, assessment, validity, data extraction, and analysis were undertaken as specified by the Cochrane Collaboration and the GRADE working group. For trials, we pooled data for weight change using inverse variance models with random effects. We pooled cohort study data where possible to estimate effect sizes, expressed as odds ratios for risk of obesity or $\beta$ coefficients for change in adiposity per unit of intake.

Results 30 of 7895 trials and 38 of 9445 cohort studies were eligible. In trials of adults with ad libitum diets (that is, with no strict control of food intake), reduced intake of dietary sugars was associated with a decrease in body weight $(0.80 \mathrm{~kg}, 95 \%$ confidence interval 0.39 to 1.21 ; $\mathrm{P}<0.001)$; increased sugars intake was associated with a comparable weight increase $(0.75 \mathrm{~kg}, 0.30$ to $1.19 ; P=0.001)$. Isoenergetic exchange of dietary sugars with other carbohydrates showed no change in body weight $(0.04 \mathrm{~kg},-0.04$ to 0.13$)$. Trials in children, which involved
\end{abstract}

recommendations to reduce intake of sugar sweetened foods and beverages, had low participant compliance to dietary advice; these trials showed no overall change in body weight. However, in relation to intakes of sugar sweetened beverages after one year follow-up in prospective studies, the odds ratio for being overweight or obese increased was 1.55 (1.32 to 1.82) among groups with the highest intake compared with those with the lowest intake. Despite significant heterogeneity in one meta-analysis and potential bias in some trials, sensitivity analyses showed that the trends were consistent and associations remained after these studies were excluded.

Conclusions Among free living people involving ad libitum diets, intake of free sugars or sugar sweetened beverages is a determinant of body weight. The change in body fatness that occurs with modifying intakes seems to be mediated via changes in energy intakes, since isoenergetic exchange of sugars with other carbohydrates was not associated with weight change.

\section{Introduction}

Sugar has been a component of human diets since ancient times, with earliest reports of consumption coming from China and India, and much later from Europe after the Crusades in the 11th century. ${ }^{1}$ The suggestion that sugar might have adverse health effects has been a recurring theme for decades, with claims that high intake may be associated with an increased risk of conditions as diverse as dental caries, obesity, cardiovascular disease, diabetes, gout, fatty liver disease, some cancers, and hyperactivity. ${ }^{2-6}$ However, inadequate study design, differences in assessing dietary intake, inconsistent findings, and varying

Correspondence to: J Mann jim.mann@otago.ac.nz

Extra material supplied by the author (see http://www.bmj.com/content/345/bmj.e7492?tab=related\#webextra)

Web appendix 1: Search terms

Web appendix 2: GRADE summaries

Web appendix 3: Randomised trials excluded from analysis

Web appendix 4: Cohort studies excluded from analysis

Web appendix 5: Web figures

Web table 1: Pooled estimates of associations between sugars intakes and measures of adiposity from prospective cohort studies in adults Web table 2: Pooled estimates of associations between sugars intakes and measures of adiposity from prospective cohort studies in children 
definitions of "sugars" have precluded definitive conclusions regarding these associations.

The most consistent association has been between a high intake of sugar sweetened beverages and the development of obesity, ${ }^{7-12}$ but not all published meta-analyses have reported a statistically significant link. ${ }^{71}$ The expert consultations organised by the World Health Organization and the Food and Agriculture Organization of the United Nations and the scientific updates undertaken by $\mathrm{WHO}^{13-15}$ have adopted a classification of carbohydrates and clarified definitions of various groups of sugars including the category of "free sugars" (table $1 \Downarrow$ ). This classification enables a more standardised approach to examining potential adverse health effects.

To update the recommendations through the guideline's development process that was launched in January 2009, WHO commissioned a systematic literature review to answer a series of questions ${ }^{16}$ relating to the effects of sugars on excess adiposity. These questions asked whether reducing or increasing intake of dietary sugars influences measures of body fatness in adults and children, and whether the existing evidence provides support for the recommendation to reduce intake of free sugars to less than $10 \%$ total energy (box). ${ }^{15}$ Body fatness was selected as an outcome in view of the extent to which comorbidities of obesity contribute to the global burden of non-communicable disease.

Since the answers to the questions posed (box) were designed to inform population based dietary guidelines rather than advise individual patients, it was deemed appropriate to include cohort studies and randomised controlled trials of free living people consuming ad libitum diets (that is, with no strict control of food intake). The interventions mainly involved advice to increase or decrease intake of sugars, or of sugar containing foods or beverages, without emphasising the need to achieve weight loss.

We also examined randomised controlled trials comparing higher and lower intakes of sugars, but where energy intake was strictly controlled. Trials specifically designed to achieve weight loss were excluded. We acknowledged that the studies identified by this approach would inevitably be heterogeneous, that it would be difficult to disentangle the effects of a range of dietary changes that might occur after altering the intake of sugars, and that it might be difficult to identify a dose response. However, the findings from such an approach were expected to provide an indication of what might be achieved by population changes in intake of dietary sugars.

\section{Methods}

In accordance with the WHO guideline's development process, ${ }^{17}$ systematic reviews and meta-analyses were conducted according to the methods of the Cochrane Collaboration. ${ }^{18}$ We prepared tables summarising quality assessment, effect size, and importance of findings, from which recommendations may be derived, in the format required by the Grading of

Recommendations Assessment, Development and Evaluation (GRADE) working group. Ethical approval was not required for this research.

\section{Search strategy}

Two separate electronic searches were conducted to identify randomised trials and prospective cohort studies relating intake of dietary sugars to measures or changes of body fatness (web appendix 1). OVID Medline, Embase, PubMed, Cumulative Index to Nursing and Allied Health Literature, Scopus, and Web of Science electronic databases were searched for clinical trials and cohort studies, published up to December 2011, which met the inclusion criteria. In OVID Medline, we used the highly sensitive Cochrane search strategy to limit the first search to clinical trials, meta-analyses, and randomised controlled trials. We hand searched meta-analyses and reviews to identify studies that might have been missed.

\section{Study selection}

Two reviewers assessed titles and abstracts of all identified English language studies. Discrepancies in opinion as to whether studies should be selected for full review were resolved by discussion. A similar approach was used to determine which of these studies should be included in the formal analysis. Animal studies, cross sectional studies, and case-control studies were excluded. Studies were required to report intake of total sugars, intake of a component of total sugars (expressed in absolute amounts or as a percentage of total energy), or intake of sugar containing foods or beverages, assessed by continuous or categorical variables; and at least one measure of body fatness.

Participants were adults and children free from acute illness, but those with diabetes or other non-communicable diseases in whom conditions were regarded as stable could be included. Randomised trials were required to be of at least two weeks' duration, and prospective cohort studies were required to be of at least one year's duration. We included trials comparing diets differing in sugars intakes and in which the effect of sugars could be separated from the effects of other lifestyle or medical interventions.

Two groups of trials were identified. One group included studies in which participants in the intervention arm were advised to decrease or increase sugars, or foods and drinks containing sugars. Although such advice was generally accompanied by the recommendation to increase or decrease other forms of carbohydrate, there was no strict attempt at weight control. These trials are referred to as ad libitum studies. The other group of trials attempted to achieve isoenergetic replacement of sugars with other forms of carbohydrate. Interventions designed to achieve weight loss were excluded because the ultimate aim of the review was to facilitate the development of population based recommendations rather than nutritional recommendations for the management of obesity.

\section{Data extraction and quality assessment}

Data extraction and validity assessment were carried out independently by two reviewers, and any discrepancies resolved by discussion. For both randomised trials and cohort studies, outcomes, data relating to participants, exposure or interventions, potential effect modifiers, and study quality were extracted by use of piloted data extraction forms. In the cohort studies, we aimed to extract the least and most adjusted relative risk, odds ratio, or mean difference when comparing the most exposed group of participants with the least exposed group, or a $\beta$ coefficient for the continuous effect of a one unit change in sugars intake. We extracted these statistics separately for sugars exposures reported as baseline values or as values for change over time.

Cochrane criteria ${ }^{18}$ were used to examine validity of each randomised trial, including sequence generation, allocation concealment, blinding of participants, personnel and outcome assessors, incomplete outcome data, and selective outcome reporting. Additional review specific criteria included similarity, or not, of type and intensity of intervention in both arms, and whether the studies were funded by industries with potentially 


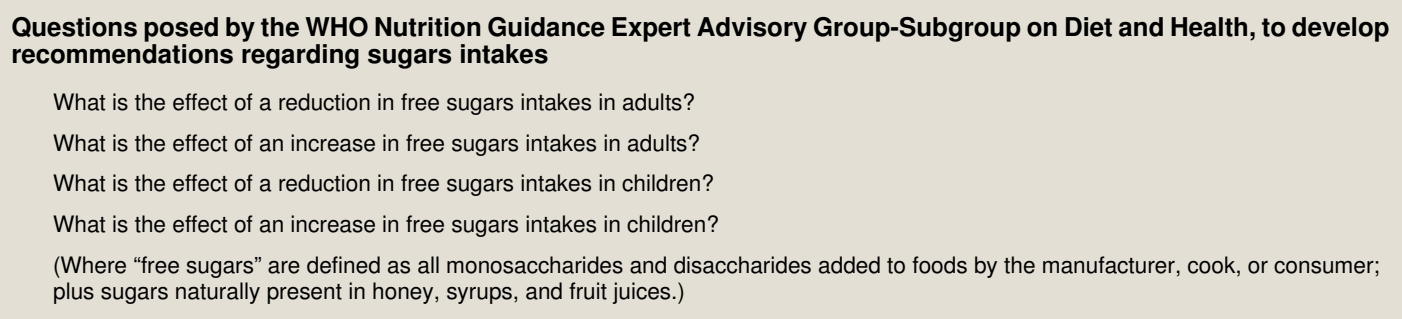

vested interests. We examined the effect of bias on the pooled effect estimates by excluding studies that had a high risk of bias for two or more validity criteria in sensitivity analyses.

\section{Statistical analysis}

Studies were grouped to answer the major questions that had been posed (box). We considered data for adults and children separately. Studies of isoenergetic exchange of sugars with other carbohydrates were examined to help explain possible mechanisms through which sugars might exert their effects.

\section{Randomised trials}

The effects of decreasing or increasing dietary sugars in adults were examined principally by meta-analysing the randomised trials in which participants were required to consume different amounts of sugar (sucrose) or other sugars (which would now be classified as "free sugars"). Terminology varied among trials. The term "free sugars" refers to all monosaccharides and disaccharides added to foods by the manufacturer, cook, or consumer, plus sugars naturally present in honey, syrups, and fruit juices (table 1) ${ }^{14}$ The term "added sugar" is sometimes used interchangeably with "free sugar" but is considered to include sugars and syrups added to foods during processing, food preparation, or at the table-but does not include honey, syrups, or fruit juice. 19 "Sugar" is generally assumed to be purified sucrose. ${ }^{14}$

Data for each group of studies were pooled using Review Manager 5.1 software. ${ }^{20}$ In trials involving adult participants, we used generic inverse variance of analysis for mean differences in body weight between intervention and control groups to compare the parallel and crossover experimental designs reporting change in body weight. In the studies involving children and adolescents, we used standardised mean differences because studies reported differences in either body mass index (BMI) or standardised BMI units.

Heterogeneity was assessed with the $\mathrm{I}^{2}$ test and Q statistics. We considered an $\mathrm{I}^{2}$ value greater than $50 \%$ and $\mathrm{P}<0.05$ as indicative of heterogeneity. ${ }^{18}$ We used random effects models because significant heterogeneity was associated with trial design and duration in some analyses.

Estimates for the standard error of the difference in means for treatment groups in crossover studies were derived from reported $P$ values when the standard error of the mean difference was not reported..$^{18}$ If $\mathrm{P}$ values for the differences were reported simply as non-significant, then $\mathrm{P}=0.2$ was assumed. ${ }^{18}$

We did sensitivity analyses to explore the differences between studies in the short term (<eight weeks) and longer term (>eight weeks). We also tested the effects of removing those studies that achieved a difference in sugars intakes of less than $5 \%$ of total energy intake between intervention and control groups. Metaregression (using Stata/IC 11.2 software for Mac (StataCorp)) was used to test for a dose-response effect of sugars on weight change, and for associations between weight change and study duration, study design (that is, crossover or parallel), and whether sugars intake changed in the intervention arm.

Publication bias among the randomised controlled trials of adults was examined by visual inspection of a funnel plot and Egger's test for bias. ${ }^{21}$ Publication bias is suspected when the funnel plot is asymmetrical. We combined the 15 ad libitum studies for this analysis because it is generally accepted that asymmetry cannot readily be assessed with 10 or fewer studies. ${ }^{18}$ Sensitivity analyses examined the influence of small study effects, by comparing the estimates derived from random and fixed effects models $^{22}$ and by using the Duval and Tweedie ${ }^{23}$ "trim and fill" method in Stata 12 (Metatrim). There were insufficient studies in children to conduct a meaningful examination of publication bias.

\section{Prospective cohort studies}

Cohort studies in adults provided limited additional information. Data from cohort studies in children were necessary to determine the effect of increasing sugars intake on adiposity, owing to a lack of suitable randomised trials. We grouped individual studies for meta-analysis on the basis of the methods used for reporting adiposity outcomes and sugars exposure variables.

We used four main methods of reporting outcomes:

- $\beta$ coefficients for the continuous association between sugars exposure at baseline and adiposity outcome.

- Odds ratios for the risk of overweight or obesity comparing participants who had the highest intakes of sugars with those who had the lowest intakes of sugars (groups or frequency of servings).

- Mean differences in change in measures of adiposity over time between participants with the highest intakes of sugars and those with the lowest intakes (groups or frequency of servings).

- $\beta$ coefficients for the continuous association between increases in sugars exposure over time and adiposity outcome.

Sugars exposures included sugar sweetened beverages, fruit juice, sweets (including jams, syrups, cakes, and desserts), sucrose, or total sugars. Exposures were reported as servings per time period and were converted to servings per day, volume of beverage consumed per day, percentage of energy intake, frequency of consumption, or grams per day. Where possible, we scaled exposures to comparable units to allow data to be pooled. We assumed that one serving of sugar sweetened beverage was equivalent to $240 \mathrm{~mL}$ or 8 fluid ounces, and contained $26 \mathrm{~g}$ of sucrose. ${ }^{24}$ This portion equated to about $5 \%$ of daily total energy intake in adults.

Measures of body fatness included weight change, change in $\mathrm{BMI}$ or BMI z score, waist circumference, body fat (\%), fat mass, and trunk fat (\%). If studies reported more than one measure of sugars intake, we derived an average effect size. We ranked adiposity outcomes in terms of importance for pooling, from highest to lowest: BMI z score, BMI, body weight, waist 
circumference, percentage body fat, fat mass, and percentage trunk fat. If studies reported outcomes for more than one measure of adiposity, we used the highest ranked adiposity outcome. We generated pooled estimates for the various subgroups using metan commands with random effects in Stata. Two sided $\mathrm{P}<0.05$ was considered significant for all analyses.

\section{GRADE assessment}

GRADE assessment ${ }^{25}$ was carried out to assess the totality of the evidence by the authors and then refined by the WHO Nutrition Guidance Expert Advisory Group (NUGAG) Subgroup on Diet and Health (www.who.int/nutrition/topics/advisory_ group/en/index.html) to fulfil the required process for developing WHO guidelines. ${ }^{17}$ GRADE assessment took into account study design limitations, consistency of results across the available studies, precision of the results, directness, and likelihood of publication bias when assessing the quality of the evidence from the randomised trials. ${ }^{17}{ }^{25}$ Further criteria were considered for the cohort studies. These criteria included magnitude of the effect, evidence of a dose-response gradient, and the direction of plausible biases. The quality of the evidence was categorised as high, moderate, low, or very low. Web appendix 2 shows the relevant GRADE tables.

\section{Results}

Figures $1 \Downarrow$ and $2 \Downarrow$ show the process by which the included studies were identified. We identified 7895 potential randomised trials from the electronic search and a further 10 studies through hand searches of relevant review articles and on recommendation from NUGAG panel members. Removing duplicates left 6634 articles, of which 6557 were assessed to be irrelevant. Abstracts and full text articles for the remaining 77 studies were judged as requiring full review and were reviewed by three independent reviewers. Of these remaining studies, 19 met the inclusion criteria for ad libitum studies ${ }^{26-47}$ and 11 were identified for the comparative analysis of isoenergetic studies. ${ }^{48-58}$ For cohort studies, we identified 9445 potential studies from the electronic search and an additional 10 studies through hand searches of relevant review articles. Of 69 studies selected for full review, 38 were considered to meet the inclusion criteria. ${ }^{59-74}$ The 47 excluded randomised trials and 31 excluded cohort studies are described in web appendices 3 and 4.

\section{Assessment of study quality}

Risk of bias varied among the randomised trials (web figs 1 and 2, web appendix 5). Failure to conceal treatment allocation (almost impossible to achieve in dietary trials involving free living participants) was the major potential source of bias (performance bias). In many trials, it was unclear as to whether outcome measures had been assessed by observers unaware of treatment allocation (detection bias) and whether there had been selection bias. Three trials, in which there was evidence of differences between dropouts and completers, reported data only for those who completed the intervention. ${ }^{28} 3439$

Our analysis included 38 prospective studies lasting at least 12 months, and in which data relating to an association between sugars and a measure of adiposity could be extracted; none was excluded on the basis of study quality. Of these 38 studies, 15 used self reported estimates of adiposity outcomes ${ }^{59} 64-68707173-80$; seven collected exposure data from questionnaires where the validity for assessing sugars intake was not stated or not assessed $^{606167798182} ; 19$ involved convenience sampling 59616267717378 83-93 ; and 18 provided estimates that were adjusted for total energy intake. ${ }^{59} 60646669727576868890-97$ There was a lack of consistency in the covariates used to adjust analyses and a wide range of methods of assessing sugars exposures and adiposity outcomes, which made pooling studies difficult.

\section{Effect of reducing dietary sugars on measures of body fatness in adults}

Table $2 \Downarrow$ describes the five studies identified for this analysis, ${ }^{28} 3031334149$ and figure $3 \Downarrow$ shows the quantitative meta-analysis (forest plot). Reduction in dietary sugars intake was associated with significantly reduced weight $(-0.80 \mathrm{~kg}$ (95\% confidence interval -1.21 to -0.39 ); $\mathrm{P}<0.001$ ) at the end of the intervention period by comparison with no reduction or an increase in sugars intake. The trials all involved a reduction in intake of sugars (classified as free sugars) in the intervention arm compared with the control arm. ${ }^{28} 31333941$ Study durations ranged from 10 weeks to eight months. In four studies, participants were advised to limit sugar containing foods,,${ }^{31} 3341$ and in one study, participants were asked to substitute usual sugar rich foods with low sugar alternatives. ${ }^{28}$ Three of the five trials reported data for completers only. ${ }^{28}{ }^{39}$ However, only two of these studies considered this to be a potential source of bias. ${ }^{28}{ }^{41}$ Exclusion of these two studies from the meta-analysis slightly attenuated the effect, although the effect estimate remained significant $(-0.81 \mathrm{~kg},-1.41$ to -0.21$)$. After excluding three studies ${ }^{28} 3941$ that had a high risk of bias for two or more validity criteria, the effect estimate was no longer significant although the difference in weight was similar $(-0.81 \mathrm{~kg},-1.69$ to 0.07 ).

Differences in sugar intakes between intervention and control groups ranged from less than $1 \%$ to $14 \%$ of total energy intake. ${ }^{39}$ Two studies achieved a difference in reported sugars intake of less than $5 \%$ of total energy intake at the end of the intervention. ${ }^{28}{ }^{33}$ Paineau and colleagues ${ }^{33}$ reported a difference in sugars intake between groups of $2.2 \mathrm{~g} / \mathrm{day}$, and Gatenby and colleagues $^{28}$ reported a difference of about $3 \%$ of energy intake ( $15 \mathrm{~g} /$ day). Exclusion of these studies from the meta-analysis strengthened the overall effect of lowered sugar intakes on body weight change $(-1.22 \mathrm{~kg}, 95 \%$ confidence interval -1.81 to $-0.63)$. We saw no evidence of heterogeneity $\left(I^{2}=17 \%, P=0.3\right)$, and the test for overall effect showing an association between sugar reduction and increased weight loss was highly significant.

\section{Effects of increasing dietary sugars on measures of body fatness in adults}

Table $3 \Downarrow$ describes the 10 studies identified for this analysis, and figure $4 \Downarrow$ shows the quantitative meta-analysis (forest plot). ${ }^{26} 32$ 34 36-38 43-45 47 Because there was statistical evidence for significant heterogeneity among the studies $\left(\mathrm{I}^{2}=82 \%, \mathrm{P}<0.001\right)$, we used a random effects model to derive the pooled estimates. Increased intake in dietary sugars was associated with significantly greater weight $(0.75 \mathrm{~kg}(95 \%$ confidence interval 0.30 to 1.19 ); $\mathrm{P}=0.001$ ) at the end of the intervention period by comparison with no increase in sugars intake. The studies involved an increase in dietary sugars; mostly sugar sweetened beverages, in the intervention arm of the randomised trial. Only two studies lasted longer than eight weeks. ${ }^{34} 36$ Subgroup analysis for these two longer term studies resulted in a significantly greater effect size $(2.73 \mathrm{~kg}, 1.68$ to 3.78$)$ than the pooled effect for the shorter term studies $(0.52 \mathrm{~kg}, 0.14$ to 0.89$)$. The difference between these subgroups was highly significant $(\mathrm{P}<0.001)$.

One trial reported a higher rate of participant dropout in the high sugars group than in the low sugars group and presented 
results for only participants who completed the whole study. ${ }^{37}$ Exclusion of this study from the meta-analysis increased the overall effect size slightly $(0.83 \mathrm{~kg}, 95 \%$ confidence interval 0.31 to 1.35 ). The association also remained significant after excluding from the meta-analysis five studies ${ }^{26} 323473$ that had a high risk of bias for two or more validity criteria $(0.96 \mathrm{~kg}$, 0.06 to 1.85 ).

\section{Isoenergetic exchanges of dietary sugars with other carbohydrates or other macronutrient sources}

We identified 12 studies that involved isoenergetic exchange of dietary sugars with other macronutrients (table $4 \Downarrow$ ). ${ }^{48-58}$

Interventions ranged from two weeks to six months, and sugars were in the form of either sucrose or fructose used to sweeten foods or liquids. We saw no evidence of difference in weight change as a result of differences in sugars intakes when energy intakes were equivalent $(0.04 \mathrm{~kg}$ ( $95 \%$ confidence interval -0.04 to 0.13 ); fig $5 \Downarrow$ ).

\section{Findings of cohort studies}

Table $5 \Downarrow$ describes 16 cohort studies in adults that provided analyses of the relation between sugars exposures and measures of adiposity. ${ }^{59-62} 64-7476$ With a vote counting approach, 11 studies reported one or more significantly positive associations between a sugars exposure and a measure of adiposity, ${ }^{59-62} 646568-717374$ and one study reported a significantly negative association. ${ }^{73}$ Two studies reporting changes in intake of sugar sweetened beverages during follow-up showed a significantly greater increase in weight change among participants with the highest intake than in those with the lowest intake. ${ }^{71}{ }^{74}$ Web table 1 summarises pooled estimates for the relation between sugars intakes and various measures of adiposity from all other prospective studies in adults that met the inclusion criteria. Forest plots for these comparisons are provided in web figures 3-5 (web appendix 5).

\section{Effects of reducing dietary sugars on measures of body fatness in children}

Table $6 \Downarrow$ describes the five intervention trials identified for this analysis, and figure $6 \Downarrow$ shows the forest plot. ${ }^{27} 29334046$ Interventions generally included advice to reduce sugar sweetened beverages and other foods containing (free) sugars. We saw no association between such advice to reduce intake of dietary sugars and change in standardised BMI or BMI z score in children $(0.09,95 \%$ confidence interval -0.14 to 0.32$)$. The studies included in this meta-analysis involved advice to reduce the intake of sugar sweetened beverages alone, ${ }^{27} 29$ or together with a further reduction in other sugar rich foods and an increase in dietary fibre. ${ }^{33}{ }^{46}$ Poor compliance with the intervention advice was reported in three of the five studies, ${ }^{29} 3346$ and the effect of the intervention was a reduction of $51 \mathrm{~mL} /$ day in another study. ${ }^{40}$ Significant heterogeneity was observed and a random effects model was used for the meta-analysis. Excluding the study by Davis and colleagues ${ }^{46}$ which had a high risk of bias for two or more validity criteria, did not alter the effect estimate.

\section{Effects of increasing dietary sugars on measures of body fatness in children}

There were no randomised trials available in children, thus we used data from 21 cohort studies in children (reported in 22 articles) to assess the effect of increasing sugars intakes on body fatness (table $7 \Downarrow$ ). Most studies related to intake of sugar sweetened beverages. A quantitative meta-analysis (fig $7 \Downarrow$ ) was based on five cohort studies, with seven comparisons. These studies reported data for the odds of being overweight at follow-up in children consuming about one daily serving of sugar sweetened beverages at baseline compared with children consuming none or very little. ${ }^{80}{ }^{94-97}$ Comparison of the higher intakes with lower intakes suggested a significantly increased risk of being overweight associated with higher intakes (odds ratio $1.55,95 \%$ confidence interval 1.32 to 1.82 ). We saw no evidence of heterogeneity, and all the studies reported a positive association. When assessing the 23 cohort studies in children using a "vote counting" approach, 15 reported a positive association between increased sugars intake and a measure of adiposity. ${ }^{75} 79-82868889919294-98$ Fourteen of these 15 studies reported the sugars exposure as a sugar sweetened beverage. By contrast, only four studies reported a negative association, ${ }^{87} 909398$ of which two reported fruit juice as the sugars exposure. ${ }^{90} 98$

Web table 2 summarises pooled and unpooled estimates for the association between sugars intakes and measures of adiposity from all other prospective studies in children that met the inclusion criteria. Because of the wide variation in how the study effects were reported, it was not always possible to pool studies reporting similar outcomes, and there was no evidence of association between increased sugars and adiposity. Web figures 6 and 7 (web appendix 5) show forest plots.

\section{Sensitivity analyses}

The overall meta-regression of randomised trials examining the effect of sugars on adiposity in adults showed no evidence of a dose-response association between sugar as a percentage of total energy intake and body weight $(0.02 \mathrm{~kg}$ (95\% confidence interval -0.03 to 0.08$) ; \mathrm{P}=0.392$ ). The difference in weight changes associated with differing intakes of sugars was unrelated to study design (crossover or parallel design trials; $0.30 \mathrm{~kg}$ ( -0.44 to 1.05$) ; \mathrm{P}=0.393)$, study duration $(0.01 \mathrm{~kg}$ per week ( -0.02 to 0.05$) ; \mathrm{P}=0.460)$, or whether sugars intakes were reduced or increased in the intervention arm relative to the control arm (0.12 kg ( -0.73 to 0.96$) ; \mathrm{P}=0.817)$.

\section{Publication bias}

The funnel plot of all 15 randomised ad libitum trials conducted in adults was asymmetrical and the Egger's test for bias was significant $(\mathrm{P}=0.001)$, which suggested possible publication bias (fig $8 \Downarrow$ ). The pooled effect size for all 15 trials was 0.78 $\mathrm{kg}(95 \%$ confidence interval 0.43 to 1.12$)$, based on a random effects model which accounted for significant heterogeneity $\left(I^{2}=77 \%, P<0.001\right)$ seen between the relatively short term crossover trials with small variances and the longer term parallel trials with larger variances. Use of fixed effects models attenuated the overall effect $(0.42 \mathrm{~kg}, 0.28$ to 0.56$)$, but it remained significant. Excluding the studies with the largest study variances ${ }^{3441}$ from the analysis had little effect $(0.72,0.37$ to 1.06). Trim and fill analysis showed a somewhat attenuated but significant effect size $(0.50,0.18$ to 0.21$)$. Visual inspection of the funnel plot and the Egger's test for bias $(\mathrm{P}=0.248)$ did not suggest publication bias among the isoenergetic trials.

\section{Discussion}

The meta-analyses based on controlled trials provide consistent evidence that increasing or decreasing intake of dietary sugars from current levels of intake is associated with corresponding changes in body weight in adults. Although some evidence of potential publication bias existed, this did not seem to have an 
important effect on the findings. Results from cohort studies were generally comparable with the trial findings. The reviewed studies largely related to the manipulation or observation of intake of sugars which, using current terminology, would be described as "free sugars." Two six month trials, ${ }^{99} 100$ published subsequent to the census date for this systematic review, involved different intakes of sugar sweetened beverages in adults. The trials also showed a trend towards increased body weight in participants with raised intake, but the difference between groups was not significant, perhaps owing to small number of participants.

Poor compliance with dietary advice could explain why the data from trials in children were equivocal. This was confirmed by two controlled trials published after our systematic review's census date. ${ }^{101} 102$ De Ruyter and colleagues ${ }^{101}$ showed a smaller increase in BMI z score after 18 months among trial completers who were provided with sugar free, artificially sweetened beverages, compared with participants who received equal quantities of sugar sweetened beverages. Ebbeling and colleagues ${ }^{102}$ showed the potential of an intervention designed to decrease the consumption of sugar sweetened beverages in overweight and obese adolescents. BMI and body weight were significantly reduced after one year in the intervention group compared with the control group. However, after a further year's follow-up with no further intervention, the difference between the groups was no longer significant.

Cohort studies in children confirmed a link between intake of sugar sweetened beverages and the risk of becoming overweight, but showed no consistent associations between other measures of sugars intake and adiposity. Although comparison of groups with the highest versus lowest intakes in cohort studies was compatible with a recommendation to restrict intake to below $10 \%$ total energy, currently available data did not allow formal dose-response analysis.

\section{Strengths and limitation}

An important strength of this in depth review of the literature lay in the overall quality and consistency of the data, especially those derived from adult populations. Although the trials were published over a long timeframe and used different experimental approaches, the results were consistent. Evidence was derived principally from randomised trials, but data from cohort studies that compared higher and lower groups of intake were also confirmatory. Criteria from both GRADE ${ }^{25}$ and the World Cancer Research Fund ${ }^{103}$ for judging strength of evidence of association specify randomised controlled trials as the highest level of evidence, but evidence from another study type is recognised as providing important confirmation.

We found less consistent findings from the trials conducted in children, which can be attributed to several factors. These trials tended to last longer than adult trials, and where compliance was assessed, it was clear that adherence to dietary advice (typically advice to reduce sugar sweetened beverages) was poor. For example, in a trial by Davis and colleagues ${ }^{46}$ children receiving nutrition education to improve carbohydrate quality achieved a reduction in added sugars intake of only $8 \mathrm{~g} / \mathrm{day}$, compared with control children. However, in children (as in adults), comparison of the highest intakes with the lowest intakes (usually of sugar sweetened beverages) suggested that those participants consuming the largest quantities had a higher body weight or other measure of adiposity.

The limitations of these findings are those inherent to the primary research on which they are based, notably inadequacy of dietary intake data, and variation in the nature and quality of the dietary intervention. Most cohort studies and some trials reported effects largely or solely related to the consumption of sugar sweetened beverages. Most trials involved different levels of intake of sugar (sucrose) and other monosaccharides and disaccharides in the control and intervention arms. These compounds have been described as "free sugars," as defined by WHO (all monosaccharides and disaccharides added to foods by the manufacturer, cook, or consumer, plus sugars naturally present in honey, syrups, and fruit juices). ${ }^{14} \mathrm{We}$ had originally intended to report separately on the effects of total sugars as well as the various subcategories of sugars, but presentation of data in the studies precluded such analyses.

Assessment of dietary intake of sugars, whether by some method of recall as used in the trials, or by food frequency questionnaires as in cohort studies, was associated with a considerable degree of measurement error even when using validated methods. This is probably one explanation why a dose-response effect could not be shown between change in dietary intake and magnitude of weight change. Nevertheless, even crude estimates of intake provided assistance in interpreting potentially inconsistent findings. The studies of long term intervention in children 2729334046 and two studies of interventions reducing dietary sugars in adults ${ }^{28}{ }^{33}$ found little difference in intakes between intervention and control groups, and no meaningful change in weight.

The heterogeneity of the studies, especially in terms of the consequences of altering intake of sugars in ad libitum diets, resulted in difficulties in fully explaining the effects of different dietary changes. Nevertheless, the changes in weight observed in studies of adults provided some indication of what might be achieved by the implementation of a dietary guideline relating to sugar, and conversely what might occur if consumption continued to increase.

The potential problem of residual confounding to explain some or all of an effect is inherent to all cohort studies. However, the overall consistency of our findings, regardless of study type, is reassuring. The only potential major source of bias identified in the trials was that four trials in adults reported data for completers. These data could have overestimated the effect, but we saw no meaningful difference in the magnitude of the effect between these trials and the other studies. Both participants and researchers in many of the trials were not blinded to intervention allocation. Studies providing beverages as a means of manipulating sugars intakes were blinded, but blinding was clearly not possible in studies relying on the provision of dietary advice to manipulate sugars intake. However, we do not believe that a lack of blinding altered our findings substantially.

Measurement of body weight did not involve judgment that was subject to bias.

\section{Potential mechanisms}

The most obvious mechanism by which increasing sugars might promote weight gain is by increasing energy consumption to an extent that exceeds energy output and distorts energy balance. For sugar sweetened beverages, it has been suggested that energy in liquid form could be less satiating than when derived from solid foods, resulting in increased consumption. ${ }^{104}$ Solid foods containing sugars are typically (although not invariably) energy dense, and frequent and substantial consumption of energy dense foods is associated with excessive weight gain and other measures of excess adiposity. We observed that isoenergetic replacement of dietary sugars with other macronutrients resulted in no change in weight (fig 5). This finding strongly suggested that energy imbalance is a major determinant of the potential 
for dietary sugars to influence measures of body fatness. However, other less direct mechanisms independent of energy balance have been proposed.

Sugars (particularly table sugar, sucrose, and high fructose corn syrup) contribute to the intake of fructose, which in turn can, at least in some people, increase levels of uric acid and hyperinsulinaemia. ${ }^{105}$ Hyperuricaemia has been identified as a potentially important and independent predictor of obesity and the metabolic syndrome. ${ }^{2}$ Sugar sweetened beverages and other sources of dietary fructose have been suggested to promote the deposition of liver, skeletal, and visceral fat and an increase in serum lipids independently of an effect on body weight. ${ }^{106}$ Although this issue is relevant to any overarching discussion regarding the health consequences of dietary sugars and the extent to which they should be restricted, it is beyond the scope of this review.

\section{Results in the context of existing knowledge}

Most of the relevant published studies, reviews, and meta-analyses related to the association between intake of sugar sweetened beverages and body weight, weight gain, or other measures of adiposity. Widely discrepant conclusions have emerged, ranging from strong or convincing evidence for an association $^{8107}$ to evidence described as inconclusive or equivocal. $^{3} 7111^{108-110}$ This variance is hardly surprising, owing to the poor compliance in most intervention trials, the insensitive instruments used for assessing dietary intakes in cohort studies, and that in such studies, intakes might have changed between initial dietary assessment and measurement of outcome. One meta-analysis combined data for adults and children. ${ }^{11}$ We found no evidence for an association between intake and weight in children when considering the intervention trials, nor were the data sufficient to examine for a dose-response effect when considering $\beta$ coefficients for the continuous association between baseline sugars exposure and adiposity outcome. Nevertheless, we were able to show a consistent effect when comparing groups with the highest intakes of sugars with those with the lowest intakes.

There have been fewer reviews and meta-analyses relating to sugars or sugar rather than sugar sweetened beverages. In a systematic review and meta-analysis, Sievenpiper and colleagues concluded that isoenergetic substitution of fructose for other carbohydrates was not associated with weight gain. ${ }^{110}$ However, free fructose at high doses that provided excess calories modestly increased body weight to an extent probably due to the extra calories rather than any particular metabolic attributes of fructose. Dolan and colleagues ${ }^{111}$ drew similar conclusions when reviewing studies in which fructose was fed at "normal levels of intake." Van Baak and Astrup ${ }^{3}$ and Ruxton ${ }^{104}$ recently concluded that there was insufficient evidence to indicate that replacing sugars with other carbohydrates resulted in a reduction in body weight. However, by limiting analyses to ad libitum trials, and considering studies in adults and children separately, our systematic review showed a clear positive association between higher intake of sugars and body fatness in adults, and provided an explanation as to why the findings in children were less conclusive.

\section{Conclusions}

This series of meta-analyses provides evidence that intake of sugars is a determinant of body weight in free living people consuming ad libitum diets. The data suggest that the change in body fatness that occurs with modifying intake of sugars results from an alteration in energy balance rather than a physiological or metabolic consequence of monosaccharides or disaccharides. Owing to the multifactorial causes of obesity, it is unsurprising that the effect of reducing intake is relatively small. The extent to which population based advice to reduce sugars might reduce risk of obesity cannot be extrapolated from the present findings, because few data from the studies lasted longer than ten weeks. However, when considering the rapid weight gain that occurs after an increased intake of sugars, it seems reasonable to conclude that advice relating to sugars intake is a relevant component of a strategy to reduce the high risk of overweight and obesity in most countries.

We thank Carolyn Summerbell and Bernard Venn for their help on the initial development of this research; Melissa Butt and Sarah Harvey, who contributed to the data search for the randomised controlled trials; Marcus Du, who contributed to the data search and extraction for the cohort studies; and the members of the WHO NUGAG Subgroup on Diet and Health for their contribution to this work.

WHO agreed to the publication of this systematic review in a scientific journal, because it serves as the background evidence review for updating $\mathrm{WHO}$ guidelines on total sugars intake and should therefore, be available widely.

Contributors: The questions for the review were discussed and developed by the WHO NUGAG Subgroup on Diet and Health in February 2010, and the protocol was approved by the NUGAG Subgroup on Diet and Health. LT and SM supervised study searches. LT, SM, and JIM assessed inclusion, extracted data, and assessed validity. LT did the meta-analyses. LT and JM wrote the manuscript. The NUGAG Subgroup on Diet and Health reviewed the first draft of the report and contributed to the GRADE assessment. All authors read and approved the final draft of the report.

Funding: The authors were supported by the University of Otago and the Riddet Institute, a New Zealand National Centre of Research Excellence. The research was supported by the University of Otago, Riddet Institute, and WHO. The authors undertook the submitted work for WHO for the purposes of updating WHO guidelines on sugars intake, and WHO provided some funding to the University of Otago towards the cost of carrying out the review.

Competing interests: All authors have completed the Unified Competing Interest form at www.icmje.org/coi_disclosure.pdf (available on request from the corresponding author) and declare: support from the University of Otago, Riddet Institute, and WHO; no other financial relationships with any organisations that might have an interest in the submitted work in the previous 3 years; and no other relationships or activities that could appear to have influenced the submitted work.

Ethical approval: Not required.

Data sharing: No additional data available.

1 Kiple KF, Ornelas KC. The Cambridge world history of food. Cambridge University Press, 2000

2 Johnson RJ, Segal MS, Sautin Y, Nakagawa T, Feig DI, Kang DH, et al. Potential role of sugar (fructose) in the epidemic of hypertension, obesity and the metabolic syndrome, diabetes, kidney disease, and cardiovascular disease. Am J Clin Nutr 2007:86:899-906.

3 van Baak MA, Astrup A. Consumption of sugars and body weight. Obes Rev 2009;10(suppl 1):9-23.

4 Burt BA, Pai S. Sugar consumption and caries risk: a systematic review. J Dent Educ 2001;65:1017-23.

5 Bristol JB, Emmett PM, Heaton KW, Williamson RC. Sugar, fat, and the risk of colorectal cancer. BMJ Clin Res Ed 1985;291:1467-70.

6 Milich R, Wolraich M, Lindgren S. Sugar and hyperactivity: a critical review of empirical findings. Clin Psychol Rev 1986;6:493-513.

7 Forshee RA, Anderson PA, Storey ML. Sugar-sweetened beverages and body mass index in children and adolescents: a meta-analysis [correction in Am J Clin Nutr 2009;89:441-2]. Am J Clin Nutr 2008;87:1662-71.

8 Vartanian LR, Schwartz MB, Brownell KD. Effects of soft drink consumption on nutrition and health: a systematic review and meta-analysis. Am J Public Health 2007:97:667-75.

9 Malik VS, Schulze MB, Hu FB. Intake of sugar-sweetened beverages and weight gain: a systematic review. Am J Clin Nutr 2006;84:274-88.

10 Drewnowski A, Bellisle F. Liquid calories, sugar, and body weight. Am J Clin Nutr 2007;85:651-61. 


\section{What is already known on this topic}

Excessive intakes of dietary sugars have been linked to obesity, and a higher risk of chronic diseases, but the link with obesity is tenuous The most consistent association has been between a high intake of sugar sweetened beverages and the development of obesity No upper safe limit of intake has been agreed universally, but WHO has suggested that intakes of free sugars should be less than $10 \%$ of the total energy intake

\section{What this study adds}

Among free living people, advice to reduce free sugars was associated with an average $0.80 \mathrm{~kg}$ reduction in weight; advice to increase intake was associated with a corresponding $0.75 \mathrm{~kg}$ increase

This parallel effect seems to be due to an altered energy intake; isoenergetic replacement of sugars with other carbohydrates did not result in any change in body weight

Evidence was less consistent in children than in adults

11 Mattes RD, Shikany JM, Kaiser KA, Allison DB. Nutritively sweetened beverage consumption and body weight: a systematic review and meta-analysis of randomized experiments. Obes Rev 2011;12:346-65.

12 Gibson S. Sugar-sweetened soft drinks and obesity: a systematic review of the evidence from observational studies and interventions. Nutr Res Rev 2008;21:134-47.

13 Mann J, Cummings JH, Englyst HN, Key T, Liu S, Riccardi G, et al. FAO/WHO Scientific Update on carbohydrates in human nutrition: conclusions. Eur J Clin Nutr 2007;61:S132-7.

14 Food and Agricultural Organization of the United Nations/WHO. Carbohydrates in human nutrition. Report of a Joint FAO/WHO Expert Consultation. FAO Food Nutr Pap 1998;66:1-140

15 WHO. Diet, nutrition and the prevention of chronic diseases. World Health Organ Tech Rep Ser 2003;916:i-viii,1-149,backcover.

16 WHO. First meeting of the WHO Nutrition Guidance Expert Advisory Group (NUGAG) 2012. www.who.int/nutrition/topics/NUGAG meeting/en/index.html.

17 WHO. WHO handbook for guideline development. 2010. www.who.int/hiv/topics/mtct/grc handbook_mar2010_1.pdf.

18 Higgins JPT, Green S. Cochrane Handbook for systematic reviews of interventions version 5.0.2. www.cochrane-handbook.org.

19 Johnson RK, Appel LJ, Brands M, Howard BV, Lefevre M, Lustig RH, et al. Dietary sugars intake and cardiovascular health: a scientific statement from the American Heart Association. Circulation 2009;120:1011-20

20 Cochrane Collaboration. Review Manager (RevMan). Version 5.1. Nordic Cochrane Centre, 2011.

21 Egger M, Davey Smith G, Schneider M, Minder C. Bias in meta-analysis detected by a simple, graphical test. BMJ 1997;315:629-34.

22 Sterne JA, Sutton AJ, loannidis JP, Terrin N, Jones DR, Lau J, et al. Recommendations for examining and interpreting funnel plot asymmetry in meta-analyses of randomised controlled trials. BMJ 2011;343:d4002.

23 Duval S, Tweedie R. Trim and fill: a simple funnel-plot-based method of testing and adjusting for publication bias in meta-analysis. Biometrics 2000;56:455-63

24 United States Department of Agriculture. USDA National Nutrient Database for standard reference, release 24. 2012. www. ars.usda.gov/nutrientdata.

25 Guyatt GH, Oxman AD, Vist GE, Kunz R, Falck-Ytter Y, Alonso-Coello P, et al. GRADE: an emerging consensus on rating quality of evidence and strength of recommendations. BMJ 2008;336:924-6

26 Brynes AE, Edwards CM, Ghatei MA, Dornhorst A, Morgan LM, Bloom SR, et al. A randomised four-intervention crossover study investigating the effect of carbohydrates on daytime profiles of insulin, glucose, non-esterified fatty acids and triacylglycerols in on daytime profiles of insulin, glucose, non-ester
middle-aged men. Br J Nutr 2003:89:207-18.

27 Ebbeling CB, Feldman HA, Osganian SK, Chomitz VR, Ellenbogen SJ, Ludwig DS. Effects of decreasing sugar-sweetened beverage consumption on body weight in adolescents: A randomized, controlled pilot study. Pediatrics 2006;117:673-80.

28 Gatenby SJ, Aaron JI, Jack VA, Mela DJ. Extended use of foods modified in fat and sugar content: nutritional implications in a free-living female population. Am J Clin Nutr 1997;65:1867-73.

29 James J, Thomas P, Cavan D, Kerr D. Preventing childhood obesity by reducing consumption of carbonated drinks: cluster randomised controlled trial. BMJ 2004;328:1237.

30 Mann JI, Hendricks DA, Truswell AS, Manning E. Effects on serum-lipids in normal men of reducing dietary sucrose or starch for five months. Lancet 1970;1:870-2.

31 Mann JI, Truswell AS, Manning EB. Effects on serum lipids of reducing dietary sucrose or starch for 22 weeks in normal men. S Afr Med J 1972;46:827-34.

32 Marckmann P, Raben A, Astrup A. Ad libitum intake of low-fat diets rich in either starchy foods or sucrose: effects on blood lipids, factor VII coagulant activity, and fibrinogen. Metabolism 2000;49:731-5.

33 Paineau DL, Beaufils F, Boulier A, Cassuto DA, Chwalow J, Combris P, et al. Family dietary coaching to improve nutritional intakes and body weight control: a randomized controlled trial. Arch Pediatr Adolesc Med 2008:162:34-43.

34 Poppitt SD, Keogh GF, Prentice AM, Williams DEM, Sonnemans HMW, Valk EEJ, et al. Long-term effects of ad libitum low-fat, high-carbohydrate diets on body weight and serum lipids in overweight subjects with metabolic syndrome. Am J Clin Nutr 2002;75:11-20.

35 Raben A, Macdonald I, Astrup A. Replacement of dietary fat by sucrose or starch: effects on $14 \mathrm{~d}$ ad libitum energy intake, energy expenditure and body weight in formerly obese and never-obese subjects. Int J Obes Relat Metab Disord 1997:21:846-59.

36 Raben A, Vasilaras TH, Moller AC, Astrup A. Sucrose compared with artificial sweeteners: different effects on ad libitum food intake and body weight after $10 \mathrm{wk}$ of supplementation in overweight subjects. Am J Clin Nutr 2002;76:721-9.

37 Reid M, Hammersley R, Duffy M. Effects of sucrose drinks on macronutrient intake, body weight, and mood state in overweight women over 4 weeks. Appetite 2010;55:130-6.

38 Reid M, Hammersley R, Hill AJ, Skidmore P. Long-term dietary compensation for added sugar: effects of supplementary sucrose drinks over a 4-week period. Br J Nutr 2007;97:193-203.

39 Saris WHM, Astrup A, Prentice AM, Zunft HJF, Formiguera X, Verboeket-van de Venne WPHG, et al. Randomized controlled trial of changes in dietary carbohydrate/fat ratio and simple vs complex carbohydrates on body weight and blood lipids: the CARMEN study. Int J Obes 2000;24:1310-8.
40 Sichieri R, Trotte AP, de Souza RA, Veiga GV. School randomised trial on prevention of excessive weight gain by discouraging students from drinking sodas. Public Health Nutr 2009;12:197-202.

41 Smith JB, Niven BE, Mann JI. The effect of reduced extrinsic sucrose intake on plasma triglyceride levels. Eur J Clin Nutr 1996;50:498-504.

42 Sorensen LB, Raben A, Stender S, Astrup A. Effect of sucrose on inflammatory markers in overweight humans. Am J Clin Nutr 2005;82:421-7.

43 Szanto S, Yudkin J. The effect of dietary sucrose on blood lipids, serum insulin, platelet adhesiveness and body weight in human volunteers. Postgrad Med J 1969;45:602-7.

44 Tordoff M, Alleva A. Effect of drinking soda sweetened with aspartame or high-fructose corn syrup on food intake and body weight. Am J Clin Nutr 1990;51:963-9.

45 Werner D, Emmett PM, Heaton KW. Effects of dietary sucrose on factors influencing cholesterol gall stone formation. Gut 1984;25:269-74.

46 Davis JN, Kelly LA, Lane CJ, Ventura EE, Byrd-Williams CE, Alexandar KA, et al. Randomized control trial to improve adiposity and insulin resistance in overweight Latino adolescents. Obesity 2009;17:1542-8.

47 Aeberli I, Gerber PA, Hochuli M, Kohler S, Haile SR, Gouni-Berthold I, et al. Low to moderate sugar-sweetened beverage consumption impairs glucose and lipid metabolism and promotes inflammation in healthy young men: a randomized controlled trial. $A m \mathrm{~J}$ Clin Nutr 2011:94:479-85.

48 Bantle JP, Swanson JE, Thomas W, Laine DC. Metabolic effects of dietary fructose in diabetic subjects. Diabetes Care 1992;15:1468-76.

49 Bantle JP, Swanson JE, Thomas W, Laine DC. Metabolic effects of dietary sucrose in type II diabetic subjects. Diabetes Care 1993;16:1301-5.

50 Grigoresco C, Rizkalla SW, Halfon P, Bornet F, Fontvieille AM, Bros M, et al. Lack of detectable deleterious effects on metabolic control of daily fructose ingestion for $2 \mathrm{mo}$ in NIDDM patients. Diabetes Care 1988;11:546-50.

51 Koivisto VA, Yki-Jarvinen H. Fructose and insulin sensitivity in patients with type 2 diabetes. $J$ Intern Med 1993;233:145-53.

52 Malerbi DA, Paiva ES, Duarte AL, Wajchenberg BL. Metabolic effects of dietary sucrose and fructose in type II diabetic subjects. Diabetes Care 1996;19:1249-56.

53 Mann Jl, Truswell AS. Effects of isocaloric exchange of dietary sucrose and starch on fasting serum lipids, postprandial insulin secretion and alimentary lipaemia in human subjects. Br J Nutr 1972;27:395-405.

54 Mann JI, Truswell AS. Sucrose-free diet and serum-lipid levels. Lancet 1973;2:153-4.

55 Osei K, Bossetti B. Dietary fructose as a natural sweetener in poorly controlled type 2 diabetes: a 12-month crossover study of effects on glucose, lipoprotein and apolipoprotein metabolism. Diabet Med 1989:6:506-11.

56 Peterson DB, Lambert J, Gerring S, Darling P, Carter RD, Jelfs R, et al. Sucrose in the diet of diabetic patients--just another carbohydrate? Diabetologia 1986;29:216-20.

57 Santacroce G, Forlani G, Giangiulio S, Galuppi V, Pagani M, Vannini P. Long-term effects of eating sucrose on metabolic control of type 1 (insulin-dependent) diabetic outpatients. Acta Diabetol Lat 1990;27:365-70.

58 Swanson JE, Laine DC, Thomas W, Bantle JP. Metabolic effects of dietary fructose in healthy subjects. Am J Clin Nutr 1992;55:851-6.

59 Bes-Rastrollo M, Sanchez-Villegas A, Basterra-Gortari FJ, Nunez-Cordoba JM, Toledo E, Serrano-Martinez M. Prospective study of self-reported usual snacking and weight gain in a Mediterranean cohort: the SUN project. Clin Nutr 2010;29:323-30.

60 Dhingra R, Sullivan L, Jacques PF, Wang TJ, Fox CS, Meigs JB, et al. Soft drink consumption and risk of developing cardiometabolic risk factors and the metabolic syndrome in middle-aged adults in the community. Circulation 2007:116:480-8.

61 Drapeau V, Despres JP, Bouchard C, Allard L, Fournier G, Leblanc C, et al. Modifications in food-group consumption are related to long-term body-weight changes. Am J Clin Nutr 2004;80:29-37.

62 French SA, Jeffery RW, Forster JL, McGovern PG, Kelder SH, Baxter JE. Predictors of weight change over two years among a population of working adults: the Healthy Worker Project. Int J Obes Relat Metab Disord 1994:18:145-54

63 Halkjaer J, Sorensen TI, Tjonneland A, Togo P, Holst C, Heitmann BL. Food and drinking patterns as predictors of 6-year BMI-adjusted changes in waist circumference. Br J Nutr 2004;92:735-48.

64 Halkjaer J, Tjonneland A, Overvad K, Sorensen TI. Dietary predictors of 5-year changes in waist circumference. J Am Diet Assoc 2009;109:1356-66.

65 Halkjaer J, Tjonneland A, Thomsen BL, Overvad K, Sorensen TI. Intake of macronutrients as predictors of 5-y changes in waist circumference. Am J Clin Nutr 2006;84:789-97.

66 Hendriksen MA, Boer JM, Du H, Feskens EJ, van der AD. No consistent association between consumption of energy-dense snack foods and annual weight and waist circumference changes in Dutch adults. Am J Clin Nutr 2011;94:19-25.

67 Kvaavik E, Andersen LF, Klepp KI. The stability of soft drinks intake from adolescence to adult age and the association between long-term consumption of soft drinks and lifestyle factors and body weight. Public Health Nutr 2005;8:149-57.

68 Mozaffarian D, Hao T, Rimm EB, Willett WC, Hu FB. Changes in diet and lifestyle and long-term weight gain in women and men. N Engl J Med 2011;364:2392-404.

69 Nooyens AC, Visscher TL, Schuit AJ, van Rossum CT, Verschuren WM, van Mechelen $W$, et al. Effects of retirement on lifestyle in relation to changes in weight and waist circumference in Dutch men: a prospective study. Public Health Nutr 2005;8:1266-74. 
70 Odegaard AO, Koh WP, Arakawa K, Yu MC, Pereira MA. Soft drink and juice consumption and risk of physician-diagnosed incident type 2 diabetes: the Singapore Chinese Health Study. Am J Epidemiol 2010;171:701-8.

71 Palmer JR, Boggs DA, Krishnan S, Hu FB, Singer M, Rosenberg L, et al. Sugar-sweetened beverages and incidence of type 2 diabetes mellitus in African American women. Arch Intern Med 2008;168:1487-92.

72 Parker DR, Gonzalez S, Derby CA, Gans KM, Lasater TM, Carleton RA. Dietary factors in relation to weight change among men and women from two southeastern New England communities. Int J Obes Relat Metab Disord 1997;21:103-9.

73 Schulz M, Kroke A, Liese AD, Hoffmann K, Bergmann MM, Boeing H. Food groups as predictors for short-term weight changes in men and women of the EPIC-Potsdam cohort. J Nutr 2002;132:1335-40.

74 Schulze MB, Manson JE, Ludwig DS, Colditz GA, Stampfer MJ, Willett WC, et al. Sugar-sweetened beverages, weight gain, and incidence of type 2 diabetes in young and middle-aged women. JAMA 2004;292:927-34.

75 Berkey CS, Rockett HR, Field AE, Gillman MW, Colditz GA. Sugar-added beverages and adolescent weight change. Obes Res 2004;12:778-88.

76 Colditz GA, Willett WC, Stampfer MJ, London SJ, Segal MR, Speizer FE. Patterns of weight change and their relation to diet in a cohort of healthy women. Am J Clin Nutr 1990;51:1100-5.

77 Haerens L, Vereecken C, Maes L, De Bourdeaudhuij I. Relationship of physical activity and dietary habits with body mass index in the transition from childhood to adolescence: a 4-year longitudinal study. Public Health Nutr 2010;13:1722-8.

78 Vanselow MS, Pereira MA, Neumark-Sztainer D, Raatz SK. Adolescent beverage habits and changes in weight over time: findings from Project EAT. Am J Clin Nutr 2009:90:1489-95. Epub 2009/10/30.

79 Viner RM, Cole TJ. Who changes body mass between adolescence and adulthood? Factors predicting change in BMI between 16 year and 30 years in the 1970 British Birth Cohort. Int J Obes 2006;30:1368-74.

80 Weijs PJ, Kool LM, van Baar NM, van der Zee SC. High beverage sugar as well as high animal protein intake at infancy may increase overweight risk at 8 years: a prospective longitudinal pilot study. Nutr J 2011;10:95.

81 Faith MS, Dennison BA, Edmunds LS, Stratton HH. Fruit juice intake predicts increased adiposity gain in children from low-income families: weight status-by-environment interaction. Pediatrics 2006;118:2066-75

82 Nissinen K, Mikkila V, Mannisto S, Lahti-Koski M, Rasanen L, Viikari J, et al. Sweets and sugar-sweetened soft drink intake in childhood in relation to adult BMI and overweight. The Cardiovascular Risk in Young Finns Study. Public Health Nutr 2009;12:2018-26.

83 Blum JW, Jacobsen DJ, Donnelly JE. Beverage consumption patterns in elementary school aged children across a two-year period. J Am Coll Nutr 2005;24:93-8.

84 Butte NF, Cai G, Cole SA, Wilson TA, Fisher JO, Zakeri IF, et al. Metabolic and behavioral predictors of weight gain in Hispanic children: the Viva la Familia Study. Am J Clin Nutr 2007;85:1478-85.

85 Buyken AE, Cheng G, Gunther AL, Liese AD, Remer T, Karaolis-Danckert N. Relation of dietary glycemic index, glycemic load, added sugar intake, or fiber intake to the development of body composition between ages 2 and 7 y. Am J Clin Nutr 2008;88:755-62.

86 Fiorito LM, Marini M, Francis LA, Smiciklas-Wright H, Birch LL. Beverage intake of girls at age $5 \mathrm{y}$ predicts adiposity and weight status in childhood and adolescence. Am J Clin Nutr 2009;90:935-42.

87 Herbst A, Diethelm K, Cheng G, Alexy U, Icks A, Buyken AE. Direction of association between added sugar intake in early childhood and body mass index at age 7 years may depend on intake levels. J Nutr 2011;141:1348-54.

88 Libuda L, Alexy L, Sichert-Hellert W, Stehle P, Karaolis-Danckert N, Buyken AE, et al. Pattern of beverage consumption and long-term association with body-weight status in German adolescents-results from the DONALD study. Brit J Nutr 2008;99:13970-9.

89 Phillips SM, Bandini LG, Naumova EN, Cyr H, Colclough S, Dietz WH, et al. Energy-dense snack food intake in adolescence: longitudinal relationship to weight and fatness. Obes Res 2004;12:461-72.

90 Skinner JD, Carruth BR. A longitudinal study of children's juice intake and growth: the juice controversy revisited. J Am Diet Assoc 2001;101:432-7.

91 Stoof SP, Twisk JW, Olthof MR. Is the intake of sugar-containing beverages during adolescence related to adult weight status? Public Health Nutr 2011:1-6.

92 Striegel-Moore RH, Thompson D, Affenito SG, Franko DL, Obarzanek E, Barton BA, et al. Correlates of beverage intake in adolescent girls: the National Heart, Lung, and Blood Institute Growth and Health Study. J Pediatr 2006;148:183-7.
93 Williams CL, Strobino BA. Childhood diet, overweight, and CVD risk factors: the Healthy Start project. Prev Cardiol 2008;11:11-20.

94 Dubois L, Farmer A, Girard M, Peterson K. Regular sugar-sweetened beverage consumption between meals increases risk of overweight among preschool-aged children. J Am Diet Assoc 2007;107:924-34; discussion 34-5.

95 Ludwig DS, Peterson KE, Gortmaker SL. Relation between consumption of sugar-sweetened drinks and childhood obesity: a prospective, observational analysis. Lancet 2001;357:505-8.

96 Welsh JA, Cogswell ME, Rogers S, Rockett H, Mei Z, Grummer-Strawn LM. Overweight among low-income preschool children associated with the consumption of sweet drinks: Missouri, 1999-2002. Pediatrics 2005;115:e223-9.

97 Lim S, Zoellner JM, Lee JM, Burt BA, Sandretto AM, Sohn W, et al. Obesity and sugar-sweetened beverages in African-American preschool children: a longitudinal study. Obesity (Silver Spring) 2009;17:1262-8.

98 Johnson L, Mander AP, Jones LR, Emmett PM, Jebb SA. Is sugar-sweetened beverage consumption associated with increased fatness in children? Nutrition 2007;23:557-63.

99 Maersk M, Belza A, Stodkilde-Jorgensen H, Ringgaard S, Chabanova E, Thomsen H, et al. Sucrose-sweetened beverages increase fat storage in the liver, muscle, and visceral fat depot: a 6-mo randomized intervention study. Am J Clin Nutr. 2012;95(2):283-9. Epub 2011/12/30.

100 Tate DF, Turner-McGrievy G, Lyons E, Stevens J, Erickson K, Polzien K, et al. Replacing caloric beverages with water or diet beverages for weight loss in adults: main results of the Choose Healthy Options Consciously Everyday (CHOICE) randomized clinical trial. Am J Clin Nutr. 2012;95(3):555-63. Epub 2012/02/04.

101 de Ruyter JC, Olthof MR, Seidell JC, Katan MB. A trial of sugar-free or sugar-sweetened beverages and body weight in children. N Engl J Med. 2012;367(15):1397-406. Epub 2012/09/25.

102 Ebbeling CB, Feldman HA, Chomitz VR, Antonelli TA, Gortmaker SL, Osganian SK, et al. A randomized trial of sugar-sweetened beverages and adolescent body weight. $N$ Engl J Med. 2012;367(15):1407-16. Epub 2012/09/25.

103 World Cancer Research Fund/American Institute for Cancer Research. Food, nutrition, physical activity, and the prevention of cancer: a global perspective. AICR, 2007.

104 DiMeglio DP, Mattes RD. Liquid versus solid carbohydrate: effects on food intake and body weight. Int J Obes Relat Metab Disord 2000;24:794-800.

105 Johnson RJ, Perez-Pozo SE, Sautin YY, Manitius J, Sanchez-Lozada LG, Feig DI, et al. Hypothesis: could excessive fructose intake and uric acid cause type 2 diabetes? Endocr Rev 2009;30:96-116.

106 Silbernagel G, Machann J, Unmuth S, Schick F, Stefan N, Haring HU, et al. Effects of 4-week very-high-fructose/glucose diets on insulin sensitivity, visceral fat and intrahepatic lipids: an exploratory trial. Br J Nutr 2011;106:79-86.

107 Hu FB, Malik VS, Schulze MB. Intake of sugar-sweetened beverages and weight gain: a systematic review. Am J Clin Nutr 2006;84:274-88

108 Ruxton $\mathrm{CH}$, Gardner EJ, McNulty HM, Ruxton CHS. Is sugar consumption detrimental to health? A review of the evidence 1995-2006. Crit Rev Food Sci Nutr 2010;50:1-19.

109 Livesey G. Taylor R. Fructose consumption and consequences for glycation, plasma triacylglycerol, and body weight: meta-analyses and meta-regression models of intervention studies; but reports on isocaloric comparisons. Am J Clin Nutr 2008;88:1419-37.

110 Sievenpiper JL, de Souza RJ, Mirrahimi A, Yu ME, Carleton AJ, Beyene J, et al. Effect of fructose on body weight in controlled feeding trials: a systematic review and meta-analysis. Ann Intern Med 2012;156:291-304.

111 Dolan LC, Potter SM, Burdock GA. Evidence-based review on the effect of normal dietary consumption of fructose on development of hyperlipidemia and obesity in healthy, normal weight individuals. Crit Rev Food Sci Nutr 2010;50:53-84.

\section{Accepted: 28 October 2012}

\section{Cite this as: BMJ 2012;345:e7492}

This is an open-access article distributed under the terms of the Creative Commons Attribution Non-commercial License, which permits use, distribution, and reproduction in any medium, provided the original work is properly cited, the use is non commercial and is otherwise in compliance with the license. See: http://creativecommons.org/licenses/bync/2.0/ and http://creativecommons.org/licenses/by-nc/2.0/legalcode. 


\section{Tables}

\section{Table 1| Classification of dietary carbohydrates}

\begin{tabular}{lll} 
Class & Subgroup & Principal components \\
Sugars (1-2) & Monosaccharides & Glucose, fructose, galactose \\
\cline { 2 - 3 } & Disaccharides & Sucrose, lactose, maltose, trehalose \\
\cline { 2 - 3 } & Polyols (sugar alcohols) & Sorbitol, mannitol, lactitol, xylitol, erythritol, isomalt, maltitol \\
\cline { 2 - 3 } & Free sugars & $\begin{array}{l}\text { All monosaccharides and disaccharides added to foods by the manufacturer, cook, or consumer; } \\
\text { sugars naturally present in honey, syrups, and fruit juices }\end{array}$ \\
\hline Oligosaccharides (3-9) & Malto-oligosaccharides (a glucans) & Maltodextrins \\
\cline { 2 - 3 } & Non-a glucan oligosaccharides & Raffinose, stachyose, fructo and galacto oligosaccharides, polydextrose, inulin \\
\hline Polysaccharides $(\geq 10)$ & Starch (a glucans) & Amylose, amylopectin, modified starches \\
\cline { 2 - 3 } & Non-starch polysaccharides & $\begin{array}{l}\text { Cellulose, hemicellulose, pectin, arabinoxylans, } \beta \\
\text { mucilages, hydrocolloids }\end{array}$ \\
\hline
\end{tabular}

*Degree of polymerisation or number of monomeric (single sugar) units in brackets.

Adapted from references 13 and 14 . 


\begin{tabular}{|c|c|c|c|c|c|c|c|}
\hline \multirow[b]{2}{*}{ Study } & \multirow[b]{2}{*}{ Methods } & \multirow[b]{2}{*}{ Participants } & \multicolumn{2}{|l|}{ Diet } & \multirow[b]{2}{*}{ Outcomes } & \multirow{2}{*}{$\begin{array}{l}\text { Study } \\
\text { duration }\end{array}$} & \multirow[b]{2}{*}{ Dose } \\
\hline & & & Intervention & Control & & & \\
\hline $\begin{array}{l}\text { Gatenby } \\
1997^{28}\end{array}$ & $\begin{array}{l}\text { Randomised } \\
\text { intervention } \\
\text { study }\end{array}$ & $\begin{array}{l}31 \text { healthy women of } \\
\text { normal weight, aged } \\
18-50 \text { years }\end{array}$ & $\begin{array}{l}\text { Ad libitum diet using } \\
\text { reduced sugar foods }\end{array}$ & Usual diet & $\begin{array}{l}\text { Dietary intake, change } \\
\text { in weight }\end{array}$ & 10 weeks & $\begin{array}{l}\text { Data not clearly reported; } \\
\text { intervention reduced sugar } \\
\text { intake by about } 4 \% \text { of total } \\
\text { energy } v \text { about } 1 \% \text { of total } \\
\text { energy in control group }\end{array}$ \\
\hline $\begin{array}{l}\text { Mann } \\
1972^{30,31}\end{array}$ & $\begin{array}{l}\text { Randomised } \\
\text { controlled trial } \\
\text { (parallel design) }\end{array}$ & $\begin{array}{l}51 \text { Apparently healthy } \\
\text { male office workers from } \\
\text { one company, aged } \\
36-55 \text { years }\end{array}$ & $\begin{array}{l}\text { Ad libitum diet with } \\
\text { low sugar (sucrose) }\end{array}$ & Usual diet & $\begin{array}{l}\text { Serum lipids, body } \\
\text { weight change }\end{array}$ & 22 weeks & $\begin{array}{l}\text { Mean reduction of } 71 \mathrm{~g} / \text { day } \\
\text { in the intervention group } v \\
\text { increase of } 3 \mathrm{~g} / \text { day in } \\
\text { controls. Difference of } 11 \% \\
\text { TE }\end{array}$ \\
\hline $\begin{array}{l}\text { Paineau } \\
2008^{33}\end{array}$ & $\begin{array}{l}\text { Randomised } \\
\text { controlled trial }\end{array}$ & $\begin{array}{l}1013 \text { children from } 54 \\
\text { elementary schools in } \\
\text { Paris and } 1013 \text { parents }\end{array}$ & $\begin{array}{l}\text { Nutrition education to } \\
\text { reduce fat and sugar } \\
\text { intake and increase } \\
\text { intake of complex } \\
\text { carbohydrates }\end{array}$ & $\begin{array}{l}\text { Nutrition } \\
\text { education to } \\
\text { reduce fat intake } \\
\text { and increase } \\
\text { intake of complex } \\
\text { carbohydrates }\end{array}$ & $\begin{array}{l}\text { Changes in } \\
\text { anthropometry } \\
\text { including BMI, BMI z } \\
\text { score, and changes in } \\
\text { dietary intakes in } \\
\text { children and parents }\end{array}$ & 8 months & $\begin{array}{l}\text { Parents had reduction of } 9.6 \\
\mathrm{~g} / \text { day } v 7.3 \mathrm{~g} / \text { day. Difference } \\
\text { of }<1 \% \mathrm{TE}\end{array}$ \\
\hline $\begin{array}{l}\text { Saris } \\
2000^{39}\end{array}$ & $\begin{array}{l}\text { Randomised } \\
\text { controlled trial }\end{array}$ & $\begin{array}{l}159 \text { healthy, overweight, } \\
\text { and obese (BMI } 25-35) \\
\text { adults, aged } 20-55 \text { years }\end{array}$ & $\begin{array}{l}\text { Ad libitum diet high in } \\
\mathrm{SCHO} \text { (that is, } \\
\text { sugars) }\end{array}$ & $\begin{array}{l}\text { Ad libitum diet } \\
\text { high in complex } \\
\text { carbohydrates }\end{array}$ & $\begin{array}{l}\text { Weight change, fat } \\
\text { mass, dietary intakes, } \\
\text { lipids, fasting glucose, } \\
\text { fasting insulin, leptin }\end{array}$ & 6 months & $\begin{array}{l}\text { Increase of } 33 \mathrm{~g} / \text { day } \mathrm{SCHO} \\
\text { versus a reduction of } 44.5 \\
\mathrm{~g} / \text { day } \mathrm{SCHO} \text {. Difference of } \\
11 \% \mathrm{TE}^{\star}\end{array}$ \\
\hline $\begin{array}{l}\text { Smith } \\
1996^{41}\end{array}$ & $\begin{array}{l}\text { Randomised } \\
\text { controlled trial }\end{array}$ & $\begin{array}{l}32 \text { middle aged and } \\
\text { overweight men with } \\
\text { hypertriglyceridaemia }\end{array}$ & $\begin{array}{l}\text { Ad libitum, sugar free } \\
\text { diet }\end{array}$ & Usual diet & $\begin{array}{l}\text { Lipids, weight, dietary } \\
\text { variables }\end{array}$ & 6 months & $\begin{array}{l}\text { Reduction of } 48 \mathrm{~g} / \text { day } \\
\text { sucrose } v \text { no change. } \\
\text { Difference of about } 8 \% \mathrm{TE}\end{array}$ \\
\hline
\end{tabular}

$\mathrm{SCHO}=$ simple carbohydrates; $\mathrm{TE}=$ total energy intake.

*About $60 \%$ of all food was supplied via a controlled study shop. 


\begin{tabular}{|c|c|c|c|c|c|c|c|c|}
\hline \multirow[b]{2}{*}{ Study } & \multirow[b]{2}{*}{ Methods } & \multirow[b]{2}{*}{ Participants } & \multicolumn{2}{|c|}{ Diet } & \multirow[b]{2}{*}{ Outcomes } & \multirow{2}{*}{$\begin{array}{l}\text { Study } \\
\text { duration }\end{array}$} & \multirow[b]{2}{*}{ Dose } & \multirow[b]{2}{*}{ Notes } \\
\hline & & & Intervention & Control & & & & \\
\hline $\begin{array}{l}\text { Aeberli } \\
2011^{47}\end{array}$ & $\begin{array}{l}\text { Randomised } \\
\text { crossover } \\
\text { trial }\end{array}$ & $\begin{array}{l}29 \text { healthy normal } \\
\text { weight men aged } \\
20-50 \text { years, living } \\
\text { in and around } \\
\text { Zurich, Switzerland }\end{array}$ & $\begin{array}{l}\text { High sugars } \\
\text { (fructose, glucose, } \\
\text { or sucrose), } \\
\text { providing } 80 \mathrm{~g} / \text { day }\end{array}$ & $\begin{array}{l}\text { Moderate sugars } \\
\text { (fructose or } \\
\text { glucose), } \\
\text { providing } 40 \mathrm{~g} / \text { day }\end{array}$ & $\begin{array}{l}\text { Lipid and glucose } \\
\text { metabolism } \\
\text { (focusing on LDL } \\
\text { particle size in } \\
\text { particular), } \\
\text { inflammatory } \\
\text { markers, weight } \\
\text { change }\end{array}$ & $\begin{array}{l}3 \text { weeks per } \\
\text { treatment, } 4 \\
\text { week } \\
\text { washout } \\
\text { between } \\
\text { treatments }\end{array}$ & $\begin{array}{l}80 \mathrm{~g} / \text { day added } \\
\text { sugars } v 40 \mathrm{~g} / \text { day. } \\
\text { Difference of } 6.6 \% \\
\text { TE }\end{array}$ & $\begin{array}{l}\text { Study involved } \\
6 \text { treatments. } \\
\text { Data were } \\
\text { aggregated for } \\
\text { the intake } \\
\text { comparisons } \\
\text { between } \\
\text { moderate and } \\
\text { high sugars } \\
\text { groups }\end{array}$ \\
\hline $\begin{array}{l}\text { Brynes } \\
2003^{26}\end{array}$ & $\begin{array}{l}\text { Randomised } \\
\text { crossover } \\
\text { trial }\end{array}$ & $\begin{array}{l}17 \text { healthy middle } \\
\text { aged men with one } \\
\text { or more cardiac risk } \\
\text { factors }\end{array}$ & $\begin{array}{l}\text { High carbohydrate, } \\
\text { high sucrose diet, } \\
\text { providing additional } \\
90 \mathrm{~g} / \text { day of sucrose }\end{array}$ & $\begin{array}{l}\text { High } \\
\text { carbohydrate, high } \\
\text { glycaemic index } \\
\text { diet }\end{array}$ & $\begin{array}{l}\text { Weight change, } \\
\text { fasting lipids, } \\
\text { postprandial } \\
\text { glucose, insulin and } \\
\text { lipids, HOMA insulin } \\
\text { sensitivity }\end{array}$ & $\begin{array}{l}24 \text { days per } \\
\text { treatment }\end{array}$ & $\begin{array}{l}132 \mathrm{~g} / \text { day } v 46 \mathrm{~g} / \text { day } \\
\text { of sucrose. } \\
\text { Difference of } 14 \% \\
\text { TE }\end{array}$ & $\begin{array}{l}\text { Energy intake } \\
\text { was intended to } \\
\text { be consistent } \\
\text { between } \\
\text { treatments }\end{array}$ \\
\hline $\begin{array}{l}\text { Marckmann } \\
2000^{32}\end{array}$ & $\begin{array}{l}\text { Randomised } \\
\text { crossover } \\
\text { trial }\end{array}$ & $\begin{array}{l}20 \text { post-obese } \\
\text { adults; controls } \\
\text { matched by age, } \\
\text { height, and weight }\end{array}$ & $\begin{array}{l}\text { Ad libitum, high } \\
\text { sucrose diet }\end{array}$ & $\begin{array}{l}\text { Ad libitum high } \\
\text { starch diet }\end{array}$ & $\begin{array}{l}\text { Weight change, } \\
\text { change in fat mass }\end{array}$ & $\begin{array}{l}2 \text { weeks per } \\
\text { treatment }\end{array}$ & $\begin{array}{l}23 \% v 2.5 \% \text { total } \\
\text { energy sucrose. } \\
\text { Difference of } 20.5 \% \\
\text { TE }\end{array}$ & - \\
\hline $\begin{array}{l}\text { Poppitt } \\
2002^{34}\end{array}$ & $\begin{array}{l}\text { Randomised } \\
\text { controlled } \\
\text { trial }\end{array}$ & $\begin{array}{l}28 \text { overweight } \\
\text { adults with three or } \\
\text { more metabolic risk } \\
\text { factors }\end{array}$ & $\begin{array}{l}\text { Ad libitum, low fat, } \\
\text { high simple } \\
\text { carbohydrate diet }\end{array}$ & $\begin{array}{l}\text { Ad libitum, low fat, } \\
\text { high complex } \\
\text { carbohydrate diet }\end{array}$ & $\begin{array}{l}\text { Weight change, } \\
\text { change in energy } \\
\text { intake, waist } \\
\text { circumference, BMI, } \\
\text { lipids }\end{array}$ & 6 months & $\begin{array}{l}\text { Increase in simple } \\
\text { carbohydrate of } 87 \\
\text { g/day } v 2 \mathrm{~g} / \text { day. } \\
\text { Difference of } 14 \% \\
\text { TE }\end{array}$ & $\begin{array}{l}13 \text { participants } \\
\text { also included in } \\
\text { the CARMEN } \\
\text { study }^{39}\end{array}$ \\
\hline $\begin{array}{l}\text { Raben } \\
2002^{35}\end{array}$ & $\begin{array}{l}\text { Randomised } \\
\text { controlled } \\
\text { trial }\end{array}$ & $\begin{array}{l}41 \text { healthy } \\
\text { overweight adults } \\
\text { (BMI } 25-30) \text { aged } \\
20-50 \text { years }\end{array}$ & $\begin{array}{l}\text { Ad libitum diet } \\
\text { supplemented with } \\
\text { sucrose containing } \\
\text { foods and } \\
\text { beverages providing } \\
28 \% \text { of total energy }\end{array}$ & $\begin{array}{l}\text { Ad libitum diet } \\
\text { supplemented } \\
\text { with artificially } \\
\text { sweetened foods } \\
\text { and beverages }\end{array}$ & $\begin{array}{l}\text { Dietary intake, } \\
\text { weight, fat mass, fat } \\
\text { free mass }\end{array}$ & 10 weeks & $\begin{array}{l}\text { Increase of } 105 \\
\text { g/day sucrose } v \\
\text { decrease of } 15 \\
\text { g/day. Difference of } \\
23 \% \text { TE }\end{array}$ & - \\
\hline Reid $2007^{38}$ & $\begin{array}{l}\text { Randomised } \\
\text { controlled } \\
\text { dietary } \\
\text { intervention }\end{array}$ & $\begin{array}{l}133 \text { normal weight } \\
\text { women aged } 20-55 \\
\text { years }\end{array}$ & $\begin{array}{l}\text { Ad libitum diet with } \\
1 \mathrm{~L} / \text { day of sugar } \\
\text { sweetened } \\
\text { beverages }\end{array}$ & $\begin{array}{l}\text { Ad libitum diet } \\
\text { with } 1 \mathrm{~L} / \mathrm{day} \text { of } \\
\text { artificially } \\
\text { sweetened } \\
\text { beverages }\end{array}$ & $\begin{array}{l}\text { Mood, weight } \\
\text { change, dietary } \\
\text { intake }\end{array}$ & 4 weeks & $\begin{array}{l}\text { Sugar sweetened } \\
\text { drinks provided } 105 \\
\text { g/day of sucrose. } \\
\text { Difference of about } \\
20 \% \text { TE }\end{array}$ & $\begin{array}{l}\text { Weight change } \\
\text { data extracted } \\
\text { from figures in } \\
\text { article }\end{array}$ \\
\hline Reid $2010^{37}$ & $\begin{array}{l}\text { Randomised } \\
\text { controlled } \\
\text { dietary } \\
\text { intervention }\end{array}$ & $\begin{array}{l}53 \text { overweight } \\
\text { women (BMI } 25-30) \\
\text { aged } 20-55 \text { years }\end{array}$ & $\begin{array}{l}\text { Ad libitum diet with } \\
1 \mathrm{~L} / \text { day of sugar } \\
\text { sweetened } \\
\text { beverages }\end{array}$ & $\begin{array}{l}\text { Ad libitum diet } \\
\text { with } 1 \mathrm{~L} / \mathrm{day} \text { of } \\
\text { artificially } \\
\text { sweetened } \\
\text { beverages }\end{array}$ & $\begin{array}{l}\text { Mood, weight } \\
\text { change, dietary } \\
\text { intake }\end{array}$ & 4 weeks & $\begin{array}{l}\text { Sugar sweetened } \\
\text { drinks provided } 105 \\
\text { g/day of sucrose. } \\
\text { Difference of about } \\
20 \% \text { TE }\end{array}$ & $\begin{array}{l}\text { Weight change } \\
\text { data extracted } \\
\text { from figures in } \\
\text { article }\end{array}$ \\
\hline $\begin{array}{l}\text { Szanto } \\
1969^{43}\end{array}$ & $\begin{array}{l}\text { Crossover } \\
\text { trial }\end{array}$ & $\begin{array}{l}19 \text { apparently } \\
\text { healthy men }\end{array}$ & $\begin{array}{l}\text { High sucrose diet } \\
\text { (substituting } \\
\text { sucrose for starch) }\end{array}$ & $\begin{array}{l}\text { Low sucrose diet } \\
\text { (10 g/day) }\end{array}$ & $\begin{array}{l}\text { Glycaemic } \\
\text { responses, insulin } \\
\text { responses, lipids, } \\
\text { weight }\end{array}$ & $\begin{array}{l}2 \text { weeks per } \\
\text { treatment, } 2 \\
\text { week } \\
\text { washouts }\end{array}$ & $\begin{array}{l}438 \mathrm{~g} / \text { day } v 10 \mathrm{~g} / \text { day } \\
\text { of sucrose. } \\
\text { Difference of }>20 \% \\
\text { TE }\end{array}$ & $\begin{array}{l}2 \text { week washout } \\
\text { sufficient to } \\
\text { restore weight } \\
\text { to baseline } \\
\text { values }\end{array}$ \\
\hline $\begin{array}{l}\text { Tordoff } \\
1990^{44}\end{array}$ & $\begin{array}{l}\text { Randomised } \\
\text { crossover } \\
\text { trial }\end{array}$ & $\begin{array}{l}30 \text { healthy, normal } \\
\text { weight adults }\end{array}$ & $\begin{array}{l}\text { Ad libitum diet } \\
\text { supplemented with } \\
1135 \mathrm{~g} / \text { day of } \\
\text { HFCS-sweetened } \\
\text { soda }\end{array}$ & $\begin{array}{l}\text { Ad libitum diet } \\
\text { supplemented } \\
\text { with } 1135 \mathrm{~g} / \text { day of } \\
\text { aspartame } \\
\text { sweetened soda }\end{array}$ & $\begin{array}{l}\text { Dietary intake, } \\
\text { weight, height, } \\
\text { dietary restraint }\end{array}$ & $\begin{array}{l}3 \text { weeks per } \\
\text { treatment }\end{array}$ & $\begin{array}{l}\text { Drinks provided } 133 \\
\mathrm{~g} / \text { day } v 1 \mathrm{~g} / \text { day high } \\
\text { fructose corn syrup. } \\
\text { Difference of } 18 \% \\
\text { TE }\end{array}$ & - \\
\hline $\begin{array}{l}\text { Werner } \\
1984^{45}\end{array}$ & $\begin{array}{l}\text { Randomised } \\
\text { crossover } \\
\text { trial }\end{array}$ & $\begin{array}{l}12 \text { adults with } \\
\text { radiolucent } \\
\text { gallstones and bile } \\
\text { supersaturated with } \\
\text { cholesterol, but with } \\
\text { normal liver } \\
\text { function, insulin and } \\
\text { glucose status }\end{array}$ & $\begin{array}{l}\text { Ad libitum, high } \\
\text { sucrose } \\
\text { (>100g/day), fibre } \\
\text { depleted diet }\end{array}$ & $\begin{array}{l}\text { Ad libitum, low } \\
\text { sucrose, fibre } \\
\text { depleted diet }\end{array}$ & $\begin{array}{l}\text { Weight, dietary } \\
\text { intakes, bile, } \\
\text { cholesterol } \\
\text { saturation index, } \\
\text { bilary secretion } \\
\text { rates, bile acid pool, } \\
\text { bilary lipids, blood } \\
\text { lipids, fasting plasma } \\
\text { glucose }\end{array}$ & $\begin{array}{l}6 \text { weeks per } \\
\text { treatment }\end{array}$ & $\begin{array}{l}112 \mathrm{~g} / \text { day } v 16 \mathrm{~g} / \text { day } \\
\text { of refined sugar. } \\
\text { Difference of } 18 \% \\
\text { TE }\end{array}$ & - \\
\hline
\end{tabular}

HFCS=high fructose corn syrup; LDL=low density lipoprotein; HOMA=homeostasis model assessment for insulin sensitivity; TE=total energy intake. 


\begin{tabular}{|c|c|c|c|c|c|c|c|}
\hline \multirow[b]{2}{*}{ Study } & \multirow[b]{2}{*}{ Methods } & \multirow[b]{2}{*}{ Participants } & \multicolumn{2}{|c|}{ Diet } & \multirow[b]{2}{*}{ Outcomes } & \multirow{2}{*}{$\begin{array}{l}\text { Study } \\
\text { duration }\end{array}$} & \multirow[b]{2}{*}{ Dose } \\
\hline & & & Intervention & Control & & & \\
\hline $\begin{array}{l}\text { Bantle } \\
1992^{48}\end{array}$ & $\begin{array}{l}\text { Randomised crossover } \\
\text { trial of isocaloric } \\
\text { metabolically } \\
\text { controlled dietary } \\
\text { interventions }\end{array}$ & $\begin{array}{l}12 \text { men and women } \\
\text { with type } 2 \text { diabetes }\end{array}$ & $\begin{array}{l}\text { High fructose, high } \\
\text { carbohydrate diet } \\
\text { (55\% of energy) }\end{array}$ & $\begin{array}{l}\text { High starch, low } \\
\text { sugars, high } \\
\text { carbohydrate diet } \\
\text { ( } 55 \% \text { of energy) }\end{array}$ & $\begin{array}{l}\text { Plasma glucose, } \\
\text { urinary glucose, } \\
\text { lipids, postprandial } \\
\text { triglycerides, body } \\
\text { weight }\end{array}$ & $\begin{array}{l}4 \text { weeks per } \\
\text { treatment }\end{array}$ & $\begin{array}{l}20 \% \text { of total energy/day } \\
\text { from sucrose } v<3 \% \text { of } \\
\text { total energy/day from } \\
\text { fructose }\end{array}$ \\
\hline $\begin{array}{l}\text { Bantle } \\
1993^{49}\end{array}$ & $\begin{array}{l}\text { Randomised crossover } \\
\text { trial of isocaloric } \\
\text { metabolically } \\
\text { controlled dietary } \\
\text { interventions }\end{array}$ & $\begin{array}{l}12 \text { men and women } \\
\text { with type } 2 \text { diabetes; } \\
6 \text { with type } 1 \text { diabetes }\end{array}$ & $\begin{array}{l}\text { High sucrose, high } \\
\text { carbohydrate diet } \\
\text { (55\% of energy) }\end{array}$ & $\begin{array}{l}\text { High starch, low } \\
\text { sugars, high } \\
\text { carbohydrate diet } \\
\text { ( } 55 \% \text { of energy) }\end{array}$ & $\begin{array}{l}\text { Plasma glucose, } \\
\text { urinary glucose, } \\
\text { lipids, postprandial } \\
\text { triglycerides, body } \\
\text { weight }\end{array}$ & $\begin{array}{l}4 \text { weeks per } \\
\text { treatment }\end{array}$ & $\begin{array}{l}19 \% \text { of total energy/day } \\
\text { from sucrose } v<3 \% \text { of } \\
\text { total energy/day from } \\
\text { sucrose }\end{array}$ \\
\hline $\begin{array}{l}\text { Grigoresco } \\
1988^{50}\end{array}$ & $\begin{array}{l}\text { Randomised crossover } \\
\text { comparing isocaloric, } \\
\text { free living diets }\end{array}$ & $\begin{array}{l}8 \text { well controlled } \\
\text { adults with type } 2 \\
\text { diabetes }\end{array}$ & $\begin{array}{l}\text { Isoglucidic diet } \\
\text { replacing } 30 \mathrm{~g} / \mathrm{d} \\
\text { starch with } 30 \mathrm{~g} / \mathrm{d} \\
\text { fructose }\end{array}$ & Starch diet & $\begin{array}{l}\text { Glycaemic control, } \\
\text { glycaemic and } \\
\text { insulinaemic } \\
\text { responses, uric acid, } \\
\text { lipids, body weight }\end{array}$ & 2 months & $\begin{array}{l}30 \mathrm{~g} / \text { day of fructose } v \\
30 \mathrm{~g} / \text { day of starch }\end{array}$ \\
\hline $\begin{array}{l}\text { Koivisto } \\
1993^{51}\end{array}$ & $\begin{array}{l}\text { Double blind, } \\
\text { randomised, isocaloric, } \\
\text { hospital inpatient, } \\
\text { crossover study }\end{array}$ & $\begin{array}{l}10 \text { men and women } \\
\text { with type } 2 \text { diabetes }\end{array}$ & $\begin{array}{l}\text { High carbohydrate } \\
\text { diet supplemented } \\
\text { with crystalline } \\
\text { fructose }\end{array}$ & $\begin{array}{l}\text { High carbohydrate } \\
\text { diet }\end{array}$ & $\begin{array}{l}\text { Glycaemic control, } \\
\text { lipid and lipoprotein } \\
\text { metabolism, insulin } \\
\text { sensitivity }\end{array}$ & 4 weeks & $\begin{array}{l}20 \% \text { of total energy } \\
\text { ( } 45-65 \mathrm{~g} / \text { day) from } \\
\text { fructose replacing } \\
\text { complex carbohydrate }\end{array}$ \\
\hline $\begin{array}{l}\text { Malerbi } \\
1996^{52}\end{array}$ & $\begin{array}{l}\text { Crossover trial of } \\
\text { isocaloric, weight } \\
\text { maintaining diets }\end{array}$ & $\begin{array}{l}16 \text { free living men } \\
\text { and women with type } \\
2 \text { diabetes }\end{array}$ & $\begin{array}{l}\text { (1) High fructose diet; } \\
\text { (2) high sucrose diet }\end{array}$ & High starch diet & $\begin{array}{l}\text { Metabolic and B cell } \\
\text { secretion effects }\end{array}$ & $\begin{array}{l}28 \text { days per } \\
\text { treatment } \\
\text { with } 14 \text { day } \\
\text { washout } \\
\text { periods }\end{array}$ & $\begin{array}{l}\text { (1) } 63 \mathrm{~g} / \text { day of fructose } \\
\text { and } 5 \mathrm{~g} / \text { day of sucrose; } \\
\text { (2) } 3 \mathrm{~g} / \text { day of fructose } \\
\text { and } 79 \mathrm{~g} / \text { day of } \\
\text { sucrose; control: } 3 \\
\mathrm{~g} / \text { day of fructose and } 14 \\
\mathrm{~g} / \text { day of sucrose }\end{array}$ \\
\hline $\begin{array}{l}\text { Mann } \\
1972 b^{53}\end{array}$ & $\begin{array}{l}\text { Randomised crossover } \\
\text { trial of hospital } \\
\text { treatments }\end{array}$ & $\begin{array}{l}9 \text { normolipidemic } \\
\text { men with history of } \\
\text { non-metabolic health } \\
\text { condition in previous } \\
\text { year }\end{array}$ & $\begin{array}{l}\text { Typical Western diet } \\
\text { with about } 140 \mathrm{~g} / \text { day } \\
\text { of sucrose }\end{array}$ & $\begin{array}{l}\text { Typical Western } \\
\text { diet with isocaloric } \\
\text { replacement of } \\
\text { sucrose with } \\
\text { complex } \\
\text { carbohydrate }\end{array}$ & Serum lipids & 14 days & $\begin{array}{l}140 \mathrm{~g} / \text { day in the } \\
\text { intervention group, } \\
\text { which was replaced with } \\
\text { starch in the control } \\
\text { group }\end{array}$ \\
\hline $\begin{array}{l}\text { Mann } \\
1973^{54}\end{array}$ & $\begin{array}{l}\text { Clinical metabolic } \\
\text { inpatient crossover } \\
\text { trial of isocaloric, } \\
\text { controlled energy diets }\end{array}$ & $\begin{array}{l}9 \text { men ( } 7 \text { with chronic } \\
\text { neurological } \\
\text { disorders, } 2 \\
\text { apparently healthy) }\end{array}$ & $\begin{array}{l}\text { High sucrose, } \\
\text { Western diet }\end{array}$ & $\begin{array}{l}\text { Normal sucrose } \\
\text { Western diet }\end{array}$ & Serum lipids & 14 days & $\begin{array}{l}160 \mathrm{~g} / \text { day } v 80 \mathrm{~g} / \text { day of } \\
\text { sucrose (difference of } \\
17 \% \mathrm{TE})^{\star}\end{array}$ \\
\hline Osei $1989^{55}$ & $\begin{array}{l}\text { Randomised crossover } \\
\text { study }\end{array}$ & $\begin{array}{l}13 \text { men and women } \\
\text { with type } 2 \text { diabetes } \\
\text { (outpatients) }\end{array}$ & $\begin{array}{l}\text { Weight maintaining, } \\
\text { diabetic, high } \\
\text { carbohydrate ( } 50 \% \text { of } \\
\text { energy), high fructose } \\
\text { diet }\end{array}$ & $\begin{array}{l}\text { Isocaloric, weight } \\
\text { maintaining, } \\
\text { diabetic diet, high } \\
\text { in complex } \\
\text { carbohydrates } \\
\text { (50\% of energy) }\end{array}$ & $\begin{array}{l}\text { Serum glucose, } \\
\mathrm{HbA}_{1 \mathrm{c}} \text {, lipids, serum } \\
\text { uric acid, serum } \\
\text { lactic acid, weight }\end{array}$ & $\begin{array}{l}6 \text { months per } \\
\text { treatment }\end{array}$ & $\begin{array}{l}60 \mathrm{~g} / \mathrm{day} \text { of crystalline } \\
\text { fructose replacing } \\
\text { complex carbohydrate }\end{array}$ \\
\hline $\begin{array}{l}\text { Peterson } \\
1986^{56}\end{array}$ & $\begin{array}{l}\text { Randomised crossover } \\
\text { trial of two } 6 \text { week } \\
\text { diets }\end{array}$ & $\begin{array}{l}23 \text { non-obese men } \\
\text { and women with type } \\
1 \text { and type } 2 \\
\text { diabetes, otherwise } \\
\text { healthy }\end{array}$ & $\begin{array}{l}\text { High sucrose diet } \\
\text { (same as for control } \\
\text { diet but } 45 \text { g/day } \\
\text { sucrose replacing } \\
\text { starch) }\end{array}$ & $\begin{array}{l}\text { High fibre, high } \\
\text { CHO diet }\end{array}$ & $\begin{array}{l}\text { Glycaemic control, } \\
\text { lipids }\end{array}$ & $\begin{array}{l}6 \text { weeks per } \\
\text { treatment }\end{array}$ & $\begin{array}{l}45 \mathrm{~g} / \text { day of sucrose } \\
\text { replaced with } 45 \mathrm{~g} / \text { day } \\
\text { of complex } \\
\text { carbohydrate }\end{array}$ \\
\hline $\begin{array}{l}\text { Santacroce } \\
1990^{57}\end{array}$ & $\begin{array}{l}\text { Randomised crossover } \\
\text { study comparing two } \\
\text { isocaloric diets }\end{array}$ & $\begin{array}{l}12 \text { adults with insulin } \\
\text { dependent diabetes }\end{array}$ & $\begin{array}{l}\text { Typical Italian, high } \\
\mathrm{CHO} \text {, low fat, diabetic } \\
\text { diet supplemented } \\
\text { with sucrose }\end{array}$ & $\begin{array}{l}\text { Typical Italian, high } \\
\text { CHO, low fat, low } \\
\text { sucrose diabetic } \\
\text { diet }\end{array}$ & $\begin{array}{l}\text { Glycaemic control, } \\
\text { lipids }\end{array}$ & $\begin{array}{l}2 \text { months per } \\
\text { treatment }\end{array}$ & $\begin{array}{l}30 \mathrm{~g} / \text { day of sucrose } \\
\text { replaced with } 30 \mathrm{~g} \text { of } \\
\text { starch }\end{array}$ \\
\hline $\begin{array}{l}\text { Swanson } \\
1992^{58}\end{array}$ & $\begin{array}{l}\text { Randomised crossover } \\
\text { design feeding trial } \\
\text { comparing } \\
\text { isoenergetic diets }\end{array}$ & $\begin{array}{l}14 \text { healthy, normal to } \\
\text { overweight men and } \\
\text { women }\end{array}$ & $\begin{array}{l}\text { High fructose }(20 \% \\
\text { TE) diet }\end{array}$ & $\begin{array}{l}\text { Low fructose }(<3 \% \\
\text { TE), high starch } \\
\text { diet }\end{array}$ & $\begin{array}{l}\text { Metabolic variables } \\
\text { including } \mathrm{HbA}_{1 \mathrm{c}} \text {, } \\
\text { glycaemic } \\
\text { responses, serum } \\
\text { lactate, lipids }\end{array}$ & $\begin{array}{l}28 \text { days per } \\
\text { treatment }\end{array}$ & $\begin{array}{l}100 \mathrm{~g} / \text { day } v 14 \mathrm{~g} / \text { day of } \\
\text { fructose } \dagger\end{array}$ \\
\hline
\end{tabular}

$\mathrm{CHO}=$ carbohydrates; $\mathrm{TE}=$ total energy intake; $\mathrm{HbA}_{10}=$ glycated haemoglobin .

*Treatments were not given in a randomised order.

†Carbohydrates differed only in the proportions of starch and fructose. 


\section{Table 5| Summary of prospective cohort studies examining association between free sugars exposures and adiposity in adults}

$\begin{array}{lcccccc}\begin{array}{l}\text { First author } \\ \text { (year), country, } \\ \text { study name }\end{array} & \begin{array}{c}\text { Population and } \\ \text { recruitment }\end{array} & \begin{array}{c}\text { Follow-up } \\ \text { (years) }\end{array} & \begin{array}{c}\text { Exposure and } \\ \text { assessment } \\ \text { method }\end{array} & \begin{array}{c}\text { Outcome and } \\ \text { assessment } \\ \text { method }\end{array} & \begin{array}{c}\text { Covariates and } \\ \text { stratification }\end{array} & \text { Findings }^{*}\end{array}$
recruitment (years)
Bes-Rastrollo 10162 Spanish

(2010), ${ }^{59}$ Spain, university graduates;

SUN Project convenience sampling
$4.4 \quad$ SSB intake

separated into

thirds; FFQ
Weight change Adjusted for age, Consumption of SSB was

$(\mathrm{kg})$ (continuous), alcohol intake, baseline associated with greater weight gain weight gain $\geq 3 \mathrm{~kg} \mathrm{BMI}$, dietary intake, in the group with the highest intake

$(\mathrm{OR})$, incident physical activity, sex, relative to the group with the obesity (HR); self sitting, smoking, total lowest. However, there was no reported energy intake, TV association with risk of developing viewing obesity

Colditz (1990), ${ }^{76} 31940$ married USA, Nurses' registered female Health Study nurses aged $30-55$ years; consecutive sampling

4 Sucrose (g/day); Weight gain (kg) Adjusted for age,

FFQ (continuous); self baseline BMI, total

reported

energy intake

Sucrose intake not significantly

associated with weight gain at

follow-up

Dhingra 4028 middle aged

Offspring Study parents were in the
(2007), ${ }^{60}$ USA, adults, mean age

Framingham 51-56 years, whose

Framingham Heart

Study; random

sampling used in

original Framingham

Heart Study cohort

$\geq 2$ servings/day); $(\mathrm{BMI} \geq 30)$ and baseline $\mathrm{BMI} / \mathrm{WC}$

questionnaire

incident high WC dietary intake,

(men $\geq 102 \mathrm{~cm}$, glycaemic index,

women $\geq 88 \mathrm{~cm}$ ) physical activity, sex

(OR); measured smoking, total energy

intake

Compared with no SSSD intake,

SSSD consumption was

associated with incident obesity (1 serving/day: OR 1.21 (95\% Cl 0.90

to 1.62 ); $\geq 1: 1.31$ (1.02 to 1.68 )

$\geq 2$ : 1.50 (1.06 to 2.11$)$ ). SSSD

consumption was significantly

associated with developing a high

WC across the intake categories

(1: 1.25 (1.02 to 1.54$) ; \geq 1: 1.40$

(1.08 to 1.83 ); $\geq 2: 1.30$ (1.09 to

1.56))

248 adults aged 18-65

(2004), ${ }^{61} \quad$ years, living within 80

Canada, $\quad \mathrm{km}$ radius of Québec;

Québec Family convenience sampling Study

In unadjusted ANCOVA analyses, participants reporting an increase in intake of sugar/sweet foods had a significantly higher increase in WC and sum of 6 skinfolds than
5.9 Self perceived Change in weight Adjusted for age, body change (increase, (kg), BF (\%), sum weight indicators at maintenance, or of 6 skinfolds baseline, change in decrease) in the $(\mathrm{cm}), W C(\mathrm{~cm})$ dietary intake, change intake of sugar, (all continuous); in physical activity sweet foods, and measured

SSSD;

questionnaire

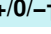
those reporting a decrease $(\mathrm{P}<0.05)$, while no differences were seen for weight change or BF (\%). No differences were seen for any body weight indicators after an increase in SSSD consumption. In adjusted regression analyses, an increase in consumption of sugar/sweet foods was significantly associated with an increased in WC $(0.16 \mathrm{~cm})$ and sum of 6 skinfolds $(1.62 \mathrm{~cm}$; both $\mathrm{P}=0.03)$

\begin{tabular}{|c|c|c|c|c|c|c|c|}
\hline $\begin{array}{l}\text { French (1994), }{ }^{62} \\
\text { USA, Healthy } \\
\text { Worker Project }\end{array}$ & $\begin{array}{l}1639 \text { working men } \\
\text { (mean age 39.1 } \\
\text { years, SD 9.8) and } \\
1913 \text { women (mean } \\
\text { age } 37.3 \text { years, SD } \\
\text { 0.7) participating in an } \\
\text { intervention study of } \\
\text { smoking cessation } \\
\text { and obesity } \\
\text { prevention; } \\
\text { convenience sampling } \\
\text { of worksites, random } \\
\text { sampling of workers }\end{array}$ & 2 & $\begin{array}{l}\text { Sweet foods and } \\
\text { SSSD } \\
\text { (servings/week); } \\
\text { FFQ }\end{array}$ & $\begin{array}{l}\text { Weight change } \\
\text { (in pounds) } \\
\text { (continuous); } \\
\text { measured }\end{array}$ & $\begin{array}{l}\text { Adjusted for dieting } \\
\text { behaviour at baseline } \\
\text { and follow-up, baseline } \\
\text { intake of sweets/SSSD, } \\
\text { baseline weight, } \\
\text { education, intervention } \\
\text { group, marital status, } \\
\text { occupation, smoking, } \\
\text { worksite; stratified by } \\
\text { sex }\end{array}$ & $\begin{array}{l}\text { Consumption of sweet foods was } \\
\text { associated with weight gain over } \\
\text { time in both men and women. Each } \\
\text { serving/week of sweet foods at } \\
\text { baseline was associated with an } \\
\text { weight increase of } 0.28 \text { pounds } \\
(0.13 \mathrm{~kg}, \mathrm{SE} 0.04 \mathrm{~kg}) \text { and } 0.19 \\
\text { pounds }(0.09 \mathrm{~kg}, 0.04 \mathrm{~kg}) \text { in } \\
\text { women and men, respectively, } \\
\text { over the } 2 \text { years (both P } \leq 0.02) \text {. No } \\
\text { significant association was seen } \\
\text { between SSSD intake and weight } \\
\text { gain }\end{array}$ & + \\
\hline $\begin{array}{l}\text { Halkjaer } \\
(2004){ }^{63} \\
\text { Denmark, } \\
\text { MONICA }\end{array}$ & $\begin{array}{l}2275 \text { Danish adults } \\
\text { aged } 30,40,50 \text {, or } 60 \\
\text { years; random } \\
\text { sampling }\end{array}$ & 6 & $\begin{array}{l}\text { Intake of sweet } \\
\text { foods divided into } \\
\text { fifths; FFQ }\end{array}$ & $\begin{array}{l}\text { Change in WC } \\
\text { (cm) } \\
\text { (continuous); } \\
\text { measured }\end{array}$ & $\begin{array}{l}\text { Adjusted for age, } \\
\text { alcohol intake, baseline } \\
\text { BMI and current BMI, } \\
\text { baseline hip } \\
\text { circumference, baseline } \\
\text { WC, change in dietary } \\
\text { intake, education, } \\
\text { physical activity, } \\
\text { smoking; stratified by } \\
\text { sex }\end{array}$ & $\begin{array}{l}\text { No relation was seen between } \\
\text { sweet foods consumption and WC }\end{array}$ & 0 \\
\hline
\end{tabular}


Table 5 (continued)

\begin{tabular}{|c|c|c|c|c|}
\hline $\begin{array}{l}\text { First author } \\
\text { (year), country, } \\
\text { study name }\end{array}$ & $\begin{array}{l}\text { Population and } \\
\text { recruitment }\end{array}$ & $\begin{array}{l}\text { Follow-up } \\
\text { (years) }\end{array}$ & $\begin{array}{l}\text { Exposure and } \\
\text { assessment } \\
\text { method }\end{array}$ & $\begin{array}{l}\text { Outcome and } \\
\text { assessment } \\
\text { method }\end{array}$ \\
\hline $\begin{array}{l}\text { Halkjaer (2006 } \\
\text { and 2009), }{ }^{6465} \\
\text { Denmark, } \\
\text { Danish Diet, } \\
\text { Cancer and } \\
\text { Health Study }\end{array}$ & $\begin{array}{l}20126 \text { men and } 22 \\
570 \text { women aged } \\
\text { 50-64 years, living in } \\
\text { greater Copenhagen } \\
\text { or Aarhus areas; } \\
\text { consecutive sampling }\end{array}$ & 5.3 & $\begin{array}{l}\text { Jams, sugars and } \\
\text { syrups ( } 250 \\
\mathrm{~kJ} / \text { day), SSSD } \\
\text { ( } 250 \mathrm{~kJ} / \text { day), and } \\
\text { energy intake from } \\
\text { foods with added } \\
\text { sugar (MJ/day); } \\
\text { FFQ }\end{array}$ & $\begin{array}{l}\text { Change in WC } \\
\text { (cm/5 years) } \\
\text { (continuous); } \\
\text { measured at } \\
\text { baseline, self } \\
\text { reported at } \\
\text { follow-up }\end{array}$ \\
\hline
\end{tabular}

\begin{tabular}{|c|c|c|}
\hline $\begin{array}{l}\text { Hendriksen } \\
(2011),{ }^{66} \\
\text { Holland, } \\
\text { MORGEN-EPIC }\end{array}$ & $\begin{array}{l}11111 \text { adults aged } \\
\text { 20-64 years, living in } \\
\text { Amsterdam, } \\
\text { Maastricht, or } \\
\text { Doetinchem; random } \\
\text { sampling }\end{array}$ & 4.9/9.9 \\
\hline
\end{tabular}

Sweets $(418$ Annual weight

\section{Covariates and \\ stratification}

Adjusted for age,

alcohol intake, baseline

intake from other

sources, physical

activity, smoking

Intake of jams, syrups, sugars, or + (women

SSSD was not associated with $\quad$ only)

change in WC in women or men.

In women only, energy intake from foods with added sugar at baseline was significantly associated with a 5 year increase in WC (per MJ/day: $0.39 \mathrm{~cm}$ increase $(95 \% \mathrm{Cl} 0.18$ to $0.60) ; \mathrm{P}<0.001$ )

$\mathrm{kJ} /$ day) and cakes change (g/year) baseline weight and

$(418 \mathrm{~kJ} /$ day $) \quad$ (continuous); self height, dietary intake,

No association between weight

intake; FFQ reported duration of follow-up,

education, physical

activity, sex, smoking,

SSSD intake, total

energy intake

\begin{tabular}{|c|c|c|c|c|c|c|c|}
\hline $\begin{array}{l}\text { Kvaavik } \\
(2004),{ }^{67} \\
\text { Norway, Oslo } \\
\text { Youth Study }\end{array}$ & $\begin{array}{l}371 \text { Norwegian adults } \\
\text { aged } 23-27 \text { years who } \\
\text { participated in a } \\
\text { school based } \\
\text { intervention study } 10 \\
\text { years previously; } \\
\text { convenience sampling }\end{array}$ & 8 & $\begin{array}{l}\text { Long term intake } \\
\text { of SSSD (low } \\
\text { consumption ( }<3 \\
\text { times/week at first } \\
\text { and second } \\
\text { follow-up), high } \\
\text { consumption ( } \geq 3 \\
\text { times/week at first } \\
\text { and second } \\
\text { follow-up), or } \\
\text { inconsistent } \\
\text { consumption); } \\
\text { questionnaire }\end{array}$ & $\begin{array}{l}\text { Prevalent } \\
\text { overweight (BMI } \\
\geq 25 \text { ) or obesity } \\
\text { (BMI } \geq 30 \text { ) at } \\
\text { second follow-up } \\
\text { (OR); self } \\
\text { reported }\end{array}$ & $\begin{array}{l}\text { Adjusted for baseline } \\
\text { (adolescent) BMI; } \\
\text { stratified by sex }\end{array}$ & $\begin{array}{l}\text { No associations were seen } \\
\text { between long term consumption of } \\
\text { SSSD and overweight or obese } \\
\text { status }\end{array}$ & 0 \\
\hline
\end{tabular}

\begin{tabular}{ll}
\hline Mozaffarian & 50422 married \\
$(2011),{ }^{68}$ USA, & registered female \\
Nurses' Health & nurses aged $30-55$ \\
Study I and II, & years, 47898 \\
Health & registered female \\
Professionals & nurses aged $24-44$ \\
Follow-up Study & years, and 120877 \\
& male health \\
& professionals aged \\
& $40-75$ years; \\
& consecutive sampling
\end{tabular}

Increase in

$\begin{array}{ll}\text { Increase in } & \text { Weight gain (in } \\ \text { consumption } & \text { pounds) over } 4\end{array}$

(servings/day) of

SSB, FJ, sweets, (continuous); self in dietary intake, increase in weight $(0.45 \mathrm{~kg}(95 \%$

or desserts; FFQ reported change in physical $\mathrm{Cl} 0.36$ to 0.53 ); $\mathrm{P}<0.001$ ). Each activity, change in serving/day increase in FJ was

smoking, change in TV associated with a 0.31 pound viewing, sleep duration increase in weight $(0.14 \mathrm{~kg}(0.06$ to 0.21$) ; P<0.001)$. Each serving/day increase in sweets or desserts was associated with a 0.41 pound increase in weight (0.19 kg, 0.07 to $0.30 ; \mathrm{P}<0.001)$

\begin{tabular}{|c|c|c|c|c|c|}
\hline $\begin{array}{l}\text { Nooyens } \\
(2005),{ }^{69} \\
\text { Holland, } \\
\text { Doetinchem } \\
\text { Cohort Study }\end{array}$ & $\begin{array}{l}288 \text { men aged } 50-60 \\
\text { years, attending a } \\
\text { municipal health } \\
\text { clinic; consecutive } \\
\text { sampling }\end{array}$ & 5 & $\begin{array}{l}\text { Change in intake } \\
\text { of SSSD } \\
\text { (glasses/day); } \\
\text { FFQ }\end{array}$ & $\begin{array}{l}\text { Change in body } \\
\text { weight (kg/year) } \\
\text { and change in } \\
\text { WC (cm/year) } \\
\text { (both } \\
\text { continuous); } \\
\text { measured }\end{array}$ & $\begin{array}{l}\text { Adjusted for age, } \\
\text { alcohol intake, dietary } \\
\text { intake, occupation, } \\
\text { physical activity, } \\
\text { retirement status, } \\
\text { smoking, total energy } \\
\text { intake }\end{array}$ \\
\hline
\end{tabular}

In unadjusted analyses, an increase in SSSD intake from baseline to follow-up was positively associated with change in body weight and WC (per glass/day increase, $\beta 0.2$ and 0.16 , respectively; both $\mathrm{P} \leq 0.04)$. After adjustment, associations were rendered non-significant (both $\mathrm{P} \geq 0.05$ )

\begin{tabular}{|c|c|c|c|c|c|c|c|}
\hline $\begin{array}{l}\text { Odegaard } \\
(2010){ }^{70} \\
\text { Singapore, } \\
\text { Singapore } \\
\text { Chinese Health } \\
\text { Study }\end{array}$ & $\begin{array}{l}43580 \text { Hokkien and } \\
\text { Cantonese speaking } \\
\text { Singaporeans aged } \\
45-74 \text { years, residing } \\
\text { in housing estates } \\
\text { built by the } \\
\text { government; } \\
\text { consecutive sampling }\end{array}$ & 5.7 & $\begin{array}{l}\text { Intake of SSSD } \\
\text { and intake of fruit } \\
\text { drinks or FJ } \\
\text { (servings per week } \\
\text { or per month); } \\
\text { FFQ }\end{array}$ & $\begin{array}{l}\text { Weight change } \\
\text { (kg) (continuous); } \\
\text { self reported }\end{array}$ & $\begin{array}{l}\text { Adjusted for age, } \\
\text { alcohol intake, BMI, } \\
\text { dialect, dietary intake, } \\
\text { education, person } \\
\text { years, sex, smoking, } \\
\text { year of interview }\end{array}$ & $\begin{array}{l}\text { Participants in the highest category } \\
\text { of SSSD consumption }(>2 \\
\text { servings/week) had a significant } \\
\text { increase in weight }(0.53 \mathrm{~kg}) \\
\text { compared with those who did not } \\
\text { consume SSSD or reported only } \\
\text { monthly consumption ( } \mathrm{P}<0.001) \text {. } \\
\text { There was no association between } \\
\text { intake of fruit drinks/FJ and change } \\
\text { in mean weight between baseline } \\
\text { and follow-up. A test for interaction } \\
\text { between SSSD intake and weight } \\
\text { gain over time was significant } \\
(\mathrm{P}=0.007)\end{array}$ & $\begin{array}{c}+(\mathrm{SSSD}) \\
0(\mathrm{FJ})\end{array}$ \\
\hline
\end{tabular}




\section{Table 5 (continued)}

$\begin{array}{ll}\begin{array}{l}\text { First author } \\ \text { (year), country, } \\ \text { study name }\end{array} & \begin{array}{c}\text { Population and } \\ \text { recruitment }\end{array} \\ \begin{array}{ll}\text { Palmer (2008), } & 71 \\ \text { USA, Black } 960 \text { African }\end{array} & \begin{array}{l}\text { American women } \\ \text { USA }\end{array} \\ \begin{array}{ll}\text { Women's Health } \\ \text { aged } 21-69 \text { years; } \\ \text { Study } & \text { convenience sampling }\end{array}\end{array}$

$\begin{array}{cc}\begin{array}{c}\text { Follow-up } \\ \text { (years) }\end{array} & \begin{array}{c}\text { Exposure and } \\ \text { assessment } \\ \text { method }\end{array}\end{array}$

Outcome and method

6 Change in intake of SSSD and

fruit drinks (servings/day); FFQ assessment

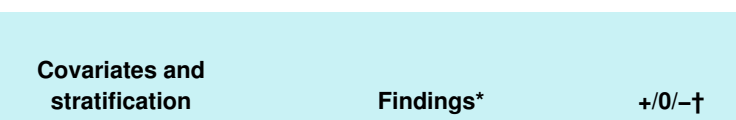

Compared with women who + (SSSD) reduced intake of SSSD ( $\geq 1$ to $\leq 1 \quad 0$ (FJ) $\begin{array}{ll}\text { intake and change in } & \text { servings/day), those who increased } \\ \text { dietary intake, } & \text { intake }(\leq 1 \text { to } \geq 1) \text { gained }\end{array}$ $\begin{array}{ll}\begin{array}{l}\text { intake and change in } \\ \text { dietary intake, }\end{array} & \text { servings/day }) \text {, those who increased } \\ \text { intake } \geq 1 \text { ) gained }\end{array}$ education, family history significantly more weight over the of diabetes, physical 6 year follow-up (4.1 kg (SD 0.22) activity and change in $\quad v 6.8 \mathrm{~kg}(0.28) ; \mathrm{P}<0.01)$. No physical activity, significant associations were noted smoking and change in between weight gain and change smoking in fruit drink intake

\begin{tabular}{|c|c|c|c|c|c|c|c|}
\hline $\begin{array}{l}\text { Parker }(1997),{ }^{72} \\
\text { USA, Pawtucket } \\
\text { Heart Health } \\
\text { Program }\end{array}$ & $\begin{array}{l}465 \text { adults aged } 18-64 \\
\text { years, participating in } \\
\text { a community based } \\
\text { programme for } \\
\text { cardiovascular } \\
\text { disease prevention; } \\
\text { random sampling }\end{array}$ & 4 & $\begin{array}{l}\text { Intake of sugar } \\
\text { (sucrose; g/day) } \\
\text { and sweets } \\
\text { (servings/week); } \\
\text { FFQ }\end{array}$ & $\begin{array}{l}\text { Weight change } \\
\text { (kg) (continuous); } \\
\text { measured }\end{array}$ & $\begin{array}{l}\text { Adjusted for age, BMI, } \\
\text { physical activity, } \\
\text { smoking, total energy } \\
\text { intake }\end{array}$ & $\begin{array}{l}\text { Intake of sucrose and sweets at } \\
\text { baseline was not associated with } \\
\text { change in weight at follow-up }\end{array}$ & 0 \\
\hline $\begin{array}{l}\text { Schulz (2002) }{ }^{73} \\
\text { Germany, } \\
\text { EPIC-Potsdam } \\
\text { Cohort }\end{array}$ & $\begin{array}{l}17396 \text { adults aged } \\
19-70 \text { years, enrolled } \\
\text { in EPIC in Potsdam; } \\
\text { convenience sampling }\end{array}$ & 2.2 & $\begin{array}{l}100 \mathrm{~g} / \text { day } \\
\text { increments in } \\
\text { intake of sweets, } \\
\text { cakes, and } \\
\text { biscuits; SSSD; } \\
\text { and desserts. FFQ }\end{array}$ & $\begin{array}{l}\text { Weight change } \\
\text { (OR; kg/year; } \\
\text { large gain }(\geq 2) \text {, } \\
\text { small gain }(1-2) \text {, } \\
\text { stable (gain or } \\
\text { loss of } 1) \text {, small } \\
\text { loss }(1-2) \text {, large } \\
\text { loss }(\geq 2) \text {; self } \\
\text { reported }\end{array}$ & $\begin{array}{l}\text { Adjusted for age, } \\
\text { baseline weight and } \\
\text { height, change in } \\
\text { dietary intake, } \\
\text { education, life and } \\
\text { health contentment, } \\
\text { drugs use, prevalent } \\
\text { diabetes, prevalent } \\
\text { stroke, weight cycling } \\
\text { history; stratified by sex }\end{array}$ & $\begin{array}{l}\text { Per } 100 \mathrm{~g} / \text { day higher increment in } \\
\text { intake of sweets at baseline, men } \\
\text { were more likely to have a large } \\
\text { gain or small loss in weight than } \\
\text { remain stable (OR } 1.48 \text { and } 1.43 \text {, } \\
\text { respectively; both } \mathrm{P}<0.05) \text {. In men, } \\
\mathrm{SSSD} \text { intake at baseline was } \\
\text { positively associated with large } \\
\text { weight gain }(\mathrm{OR} 1.03) \text {, small } \\
\text { weight loss }(1.02) \text { and large weight } \\
\text { loss ( } 1.03 ; \text { all } \mathrm{P}<0.05) \text {. Per } 100 \\
\text { g/day higher increment in intake of } \\
\text { sweets or cakes/biscuits at } \\
\text { baseline, women were less likely } \\
\text { to have a large loss in weight than } \\
\text { remain stable }(0.67 \text { and } 0.88 \text {, } \\
\text { respectively; both } \mathrm{P}<0.05) \text {. In } \\
\text { women, SSSD intake at baseline } \\
\text { was positively associated with } \\
\text { large weight loss }(1.02, \mathrm{P}<0.05)\end{array}$ & + and - \\
\hline $\begin{array}{l}\text { Schulze } \\
(2004),{ }^{74} \text { USA, } \\
\text { Nurses' Health } \\
\text { Study II }\end{array}$ & $\begin{array}{l}51603 \text { registered } \\
\text { female nurses aged } \\
24-44 \text { years; } \\
\text { consecutive sampling }\end{array}$ & 4 & $\begin{array}{l}\text { Change in } \\
\text { consumption of } \\
\text { SSSD, fruit drinks, } \\
\text { FJ (from } \leq 1 \\
\text { time/week to } \geq 1 \\
\text { time/day, } \geq 1 \\
\text { time/day to } \leq 1 \\
\text { time/week, } \\
\text { consistently } \leq 1 \\
\text { time/week, } \\
\text { consistently } \geq 1 \\
\text { time/day); FFQ }\end{array}$ & $\begin{array}{l}\text { Weight change } \\
(\mathrm{kg}) \text { and BMI } \\
\text { change (both } \\
\text { continuous); self } \\
\text { reported }\end{array}$ & $\begin{array}{l}\text { Adjusted for baseline } \\
\text { values of age, alcohol } \\
\text { intake, BMI, dietary } \\
\text { intake, oral } \\
\text { contraceptive use, } \\
\text { physical activity, } \\
\text { postmenopausal } \\
\text { hormone use, and } \\
\text { smoking, and changes } \\
\text { in all variables over time }\end{array}$ & $\begin{array}{l}\text { Women who increased } \\
\text { consumption of SSSD gained more } \\
\text { weight and reported a higher BMI } \\
\text { at follow-up than those who } \\
\text { decreased consumption or } \\
\text { maintained a high or low intake (all } \\
\mathrm{P}<0.001) \text {. Similarly, women who } \\
\text { increased consumption of fruit } \\
\text { drink/FJ gained more weight than } \\
\text { those who decreased consumption } \\
(\mathrm{P}<0.001)\end{array}$ & $\begin{array}{c}+ \\
\text { (only in } \\
\text { women } \\
\text { who } \\
\text { increased } \\
\text { intake) }\end{array}$ \\
\hline
\end{tabular}

ANCOVA=analysis of covariance; $B F=$ body fat; $F F Q=$ food frequency questionnaire; $F J=100 \%$ fruit juice; $H R=$ hazard ratio; $O R=0 d d s$ ratio; $S E=$ standard error; $\mathrm{SD}=$ standard deviation; SSSD=sugar sweetened soft drinks; SSB=sugar sweetened beverages (including cordials, energy drinks, fruit drinks, iced tea, soft drinks); TV=television; WC=waist circumference.

*Most adjusted results are reported unless otherwise stated.

†Higher sugar intake positively associated with weight gain (+), not associated with weight gain (0), and negatively associated with weight gain (-). 


\begin{tabular}{|c|c|c|c|c|c|c|c|}
\hline \multirow{2}{*}{ Study } & \multirow[b]{2}{*}{ Methods } & \multirow[b]{2}{*}{ Participants } & \multicolumn{2}{|l|}{ Diet } & \multirow[b]{2}{*}{ Outcomes } & \multirow{2}{*}{$\begin{array}{l}\text { Study } \\
\text { duration }\end{array}$} & \multirow[b]{2}{*}{ Dose } \\
\hline & & & Intervention & Control & & & \\
\hline $\begin{array}{l}\text { Davis } \\
2009^{46}\end{array}$ & $\begin{array}{l}\text { Randomised } \\
\text { controlled trial }\end{array}$ & 68 Latino adolescents & $\begin{array}{l}\text { Nutrition education on } \\
\text { carbohydrate modification with } \\
\text { targets of }<10 \% \text { total energy } \\
\text { from added sugars and }>14 \\
\mathrm{~g} / 1000 \mathrm{kcal} \text { dietary fibre }\end{array}$ & Usual diet & $\begin{array}{l}\text { Glycaemic responses, } \\
\text { insulin sensitivity, body } \\
\text { composition, change in } \\
\text { dietary intakes and } \\
\text { activity levels }\end{array}$ & 16 weeks & $\begin{array}{l}\text { Reduction in added } \\
\text { sugar intake of } 10 \\
\text { g/day } v 2 \text { g/day }\end{array}$ \\
\hline $\begin{array}{l}\text { Ebbeling } \\
2006^{27}\end{array}$ & $\begin{array}{l}\text { Randomised } \\
\text { controlled } \\
\text { intervention } \\
\text { study }\end{array}$ & $\begin{array}{l}103 \text { adolescents aged } \\
13-18 \text { years consuming } \\
\text { at least one } \\
\text { serving/day of sugar } \\
\text { sweetened beverages }\end{array}$ & $\begin{array}{l}\text { Weekly home deliveries of } \\
\text { non-caloric beverages, } \\
\text { amounting to } 4 \text { servings per } \\
\text { participant/day and two } \\
\text { servings/day for additional } \\
\text { household members, with } \\
\text { behavioural counselling by } \\
\text { telephone to encourage } \\
\text { displacement of sugar } \\
\text { sweetened beverages }\end{array}$ & $\begin{array}{l}\text { Continued usual } \\
\text { habits of beverage } \\
\text { consumption }\end{array}$ & $\begin{array}{l}\text { Change in BMI from } \\
\text { baseline to follow-up, } \\
\text { change in energy intake } \\
\text { from carbonated } \\
\text { beverages, consumption } \\
\text { of non-caloric beverages }\end{array}$ & 25 weeks & $\begin{array}{l}\text { Reduction in added } \\
\text { sugar intake of } 75 \\
\text { g/day } v 12 \mathrm{~g} / \text { day }\end{array}$ \\
\hline $\begin{array}{l}\text { James } \\
2004^{29}\end{array}$ & $\begin{array}{l}\text { Cluster } \\
\text { randomised } \\
\text { controlled trial }\end{array}$ & $\begin{array}{l}644 \text { primary school } \\
\text { children aged } 7-11 \\
\text { years from } 6 \text { schools } \\
\text { and } 29 \text { classes in UK }\end{array}$ & $\begin{array}{l}\text { Nutrition education to reduce } \\
\text { consumption of carbonated } \\
\text { beverages }\end{array}$ & $\begin{array}{l}\text { No nutrition } \\
\text { education }\end{array}$ & $\begin{array}{l}\text { Change in BMI z score, } \\
\text { change in soft drink } \\
\text { consumption }\end{array}$ & $\begin{array}{l}12 \\
\text { months }\end{array}$ & $\begin{array}{l}\text { Reduction in } 0.1 \\
\text { glasses/day of sugar } \\
\text { sweetened } \\
\text { carbonated drinks } v \\
\text { no reduction }\end{array}$ \\
\hline $\begin{array}{l}\text { Paineau } \\
2008^{33}\end{array}$ & $\begin{array}{l}\text { Randomised } \\
\text { controlled trial }\end{array}$ & $\begin{array}{l}1013 \text { children from } 54 \\
\text { elementary schools in } \\
\text { Paris, } 1013 \text { parents }\end{array}$ & $\begin{array}{l}\text { Nutrition education to reduce } \\
\text { fat and sugar intake and } \\
\text { increase intake of complex } \\
\text { carbohydrates }\end{array}$ & $\begin{array}{l}\text { Nutrition education } \\
\text { to reduce fat } \\
\text { intake and } \\
\text { increase intake of } \\
\text { complex } \\
\text { carbohydrates }\end{array}$ & $\begin{array}{l}\text { Changes in } \\
\text { anthropometry including } \\
\text { BMI, BMI z score, } \\
\text { changes in dietary } \\
\text { intakes in children and } \\
\text { parents }\end{array}$ & 8 months & $\begin{array}{l}\text { Children: reduction } \\
\text { of } 10 \mathrm{~g} / \text { day of sugar } \\
v 5.5 \mathrm{~g} / \text { day }\end{array}$ \\
\hline $\begin{array}{l}\text { Sichieri } \\
2009^{40}\end{array}$ & $\begin{array}{l}\text { Randomised, } \\
\text { controlled, } \\
\text { cluster school } \\
\text { based } \\
\text { intervention }\end{array}$ & $\begin{array}{l}1140 \text { Brazilian children } \\
\text { in the } 4 \text { th grade (age } \\
9-11 \text { years), living in } \\
\text { urban areas and of low } \\
\text { socioeconomic status }\end{array}$ & $\begin{array}{l}\text { Behavioural intervention to } \\
\text { reduce intake of sugar } \\
\text { sweetened beverages delivered } \\
\text { in the classroom in } 10 \times 1 \mathrm{~h} \\
\text { sessions }\end{array}$ & $\begin{array}{l}2 \times 1 \mathrm{~h} \text { general } \\
\text { health sessions } \\
\text { and printed advice } \\
\text { regarding healthy } \\
\text { diets }\end{array}$ & $\begin{array}{l}\text { Beverage consumption, } \\
\text { weight change, BMl }\end{array}$ & $\begin{array}{l}\text { About } 8 \\
\text { months }\end{array}$ & $\begin{array}{l}\text { Reduction in } \\
\text { carbonated } \\
\text { beverages of } 69 \\
\mathrm{~mL} / \text { day } v 13 \mathrm{~mL} / \text { day }\end{array}$ \\
\hline
\end{tabular}




\begin{tabular}{|c|c|c|c|c|c|c|c|}
\hline $\begin{array}{l}\text { First author } \\
\text { (year), } \\
\text { country, study } \\
\text { name }\end{array}$ & $\begin{array}{l}\text { Population and } \\
\text { recruitment }\end{array}$ & $\begin{array}{l}\text { Follow-up } \\
\text { (years) }\end{array}$ & $\begin{array}{l}\text { Exposure and } \\
\text { assessment } \\
\text { method }\end{array}$ & $\begin{array}{l}\text { Outcome and } \\
\text { assessment } \\
\text { method }\end{array}$ & $\begin{array}{l}\text { Covariates and } \\
\text { stratification }\end{array}$ & Findings* & $+/ 0 /-\dagger$ \\
\hline $\begin{array}{l}\text { Berkey } \\
(2004),{ }^{75} \text { USA, } \\
\text { Growing Up } \\
\text { Today Study }\end{array}$ & $\begin{array}{l}1175 \text { adolescents aged } \\
9-14 \text { years, whose } \\
\text { mothers were in the } \\
\text { Nurses' Health Study } \\
\text { II; consecutive } \\
\text { sampling used in } \\
\text { original Nurses' Health } \\
\text { Study II cohort }\end{array}$ & 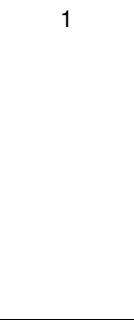 & $\begin{array}{l}\text { SSB intake } \\
\text { (serving/day) and } \\
\text { increase in SSB } \\
\text { intake (1 } \\
\text { serving/day } \\
\text { increase); FFQ }\end{array}$ & $\begin{array}{l}\text { Change in BMI } \\
\text { (continuous); self } \\
\text { reported }\end{array}$ & $\begin{array}{l}\text { Adjusted for age, } \\
\text { dietary intake, ethnicity, } \\
\text { growth, physical } \\
\text { activity, previous BMI z } \\
\text { score, screen time, } \\
\text { Tanner stage, total } \\
\text { energy intake; stratified } \\
\text { by sex }\end{array}$ & $\begin{array}{l}\text { In boys, significant associations } \\
\text { between SSB consumption at } \\
\text { baseline and } 1 \text { year weight gain, and } \\
\text { between increasing SSB consumption } \\
\text { and } 1 \text { years weight gain were seen } \\
\text { in adjusted analyses (both } \mathrm{P} \leq 0.038 \text { ). } \\
\text { After adjusting for total energy intake, } \\
\text { effect sizes in boys and girls were } \\
\text { reduced, and associations were } \\
\text { rendered non-significant }\end{array}$ & + \\
\hline $\begin{array}{l}\text { Blum (2005), } \\
\text { USA }\end{array}$ & $\begin{array}{l}164 \text { children aged } 9.3 \\
\text { years (SD 1) attending } \\
\text { elementary school; } \\
\text { convenience sampling }\end{array}$ & 2 & $\begin{array}{l}\text { SSB intake } \\
\text { (ounces/day); } 24 \mathrm{~h} \\
\text { recall }\end{array}$ & $\begin{array}{l}\text { Change in BMI z } \\
\text { score } \\
\text { (continuous); } \\
\text { measured }\end{array}$ & $\begin{array}{l}\text { Adjusted for baseline } \\
\text { BMI z score, intake of } \\
\text { diet soda at follow-up }\end{array}$ & $\begin{array}{l}\text { Regression analysis of BMI z score } \\
\text { at follow-up showed no association } \\
\text { with SSB consumption (data not } \\
\text { reported) }\end{array}$ & 0 \\
\hline $\begin{array}{l}\text { Butte (2009), } \\
\text { USA, Viva la } \\
\text { Familia Study }\end{array}$ & $\begin{array}{l}789 \text { Hispanic } \\
\text { adolescents aged 9-14 } \\
\text { years, at least } 1 \\
\text { overweight child in } \\
\text { family; convenience } \\
\text { sampling of families }\end{array}$ & 1 & $\begin{array}{l}\text { Energy intake }(\%) \\
\text { from sucrose, and } \\
\text { from added sugar; } \\
24 \mathrm{~h} \text { recall }\end{array}$ & $\begin{array}{l}\text { Weight gain }(\mathrm{kg}) \\
\text { (continuous); } \\
\text { measured }\end{array}$ & $\begin{array}{l}\text { Adjusted for age, BMI } \\
\text { status sex, Tanner } \\
\text { stage }\end{array}$ & $\begin{array}{l}\text { Energy intake from sucrose and } \\
\text { added sugars was not found to be } \\
\text { associated with weight gain }\end{array}$ & 0 \\
\hline $\begin{array}{l}\text { Dubois } \\
\text { (2007), }{ }^{94} \\
\text { Canada, } \\
\text { Longitudinal } \\
\text { Study of Child } \\
\text { Development in } \\
\text { Québec }\end{array}$ & $\begin{array}{l}380 \text { children aged } 2.5 \\
\text { years; random } \\
\text { sampling }\end{array}$ & 2 & $\begin{array}{l}\text { SSB intake } \\
\text { between meals at } \\
\text { age } 2.5,3.5 \text {, and } \\
4.5 \text { years, } \\
\text { categorised as } \\
\text { non-consumers, } \\
\text { regular consumers, } \\
\text { or other (including } \\
\text { children who } \\
\text { changed } \\
\text { consumption); FFQ }\end{array}$ & $\begin{array}{l}\text { Overweight BMI } \\
\text { ( } \geq 95 \text { th percentile) } \\
\text { at age } 4.5 \text { years } \\
\text { (OR); measured }\end{array}$ & $\begin{array}{l}\text { Adjusted for birth } \\
\text { weight, dietary intake, } \\
\text { maternal smoking, } \\
\text { number of obese } \\
\text { parents, physical } \\
\text { activity, SES, sex, total } \\
\text { energy intake }\end{array}$ & $\begin{array}{l}\text { Regular consumers were } 2.36 \text { times } \\
\text { more likely to be obese at age } 4.5 \\
\text { years than non-consumers }(95 \% \mathrm{Cl} \\
1.03 \text { to } 5.39 ; \mathrm{P} \leq 0.05)\end{array}$ & + \\
\hline $\begin{array}{l}\text { Faith }(2006),{ }^{81} \\
\text { USA }\end{array}$ & $\begin{array}{l}825 \text { children aged 1-5 } \\
\text { years enrolled in the } \\
\text { Special Nutrition } \\
\text { Program for Women, } \\
\text { Infants and Children in } \\
\text { New York State; } \\
\text { consecutive sampling }\end{array}$ & 2 & $\begin{array}{l}\text { FJ intake } \\
\text { (servings/day) } \\
\text { questionnaire }\end{array}$ & $\begin{array}{l}\text { Change in BMI z } \\
\text { score } \\
\text { (continuous); } \\
\text { measured }\end{array}$ & $\begin{array}{l}\text { Adjusted for baseline } \\
\text { weight-for-height } z \\
\text { score and weight } \\
\text { status, dietary intake, } \\
\text { parental feeding } \\
\text { behaviour; stratified by } \\
\text { being at risk of } \\
\text { overweight } \\
\text { (weight-for-height z } \\
\text { score } \geq 85 \text { th percentile) } \\
\text { and not being at risk of } \\
\text { overweight }\end{array}$ & $\begin{array}{l}\text { At follow-up, each serving/day of FJ } \\
\text { intake at baseline was associated } \\
\text { with a } 0.005 \text { increase in BMI z score } \\
(P<0.01) \text { in pooled analysis, a } 0.009 \\
\text { increase for people at risk of } \\
\text { overweight }(P<0.01) \text {, and a } \\
\text { non-significant increase of } 0.003 \text { for } \\
\text { those not at risk of overweight }\end{array}$ & + \\
\hline $\begin{array}{l}\text { Fiorito (2009), } \\
\text { USA }\end{array}$ & $\begin{array}{l}166 \text { girls aged } 5 \text { years } \\
\text { at baseline; } \\
\text { convenience sampling }\end{array}$ & 10 & $\begin{array}{l}\text { SSB intake }(<1, \geq 1 \\
\text { to }<2, \text { or } \geq 2 \\
\text { servings/day, and } \\
\text { as a continuous } \\
\text { variable); } 24 \mathrm{~h} \\
\text { recall }\end{array}$ & $\begin{array}{l}\mathrm{BF}(\%), \mathrm{WC} \\
(\mathrm{cm}), \mathrm{BMI} \\
\text { percentile, } \\
\text { overweight status } \\
\text { (\% overweight in } \\
\text { each SSB intake } \\
\text { group) (all } \\
\text { continuous); } \\
\text { measured }\end{array}$ & $\begin{array}{l}\text { Adjusted for maternal } \\
\text { BMI, parental } \\
\text { education, SSB intake } \\
\text { at } 15 \text { years, total } \\
\text { energy intake (all } \\
\text { adjusted for separately) }\end{array}$ & $\begin{array}{l}\text { SSB intake at age } 5 \text { years was a } \\
\text { significant predictor of adiposity at } \\
\text { each } 2 \text { year time point during ages } \\
5-15 \text { years in unadjusted ANOVA } \\
\text { analyses. Greater consumption of } \\
\text { SSB at } 5 \text { years was associated with } \\
\text { a higher WC at } 15 \text { years, after } \\
\text { adjusting for intake of SSB and } \\
\text { energy at } 15 \text { years and family income } \\
\text { at } 15 \text { years (all P<0.05), but } \\
\text { association was non-significant after } \\
\text { adjusting for maternal BMI and } \\
\text { parental education }\end{array}$ & + \\
\hline $\begin{array}{l}\text { Haerens } \\
(2010),{ }^{77} \\
\text { Belgium, } \\
\text { Longitudinal } \\
\text { Eating and } \\
\text { Activity Study }\end{array}$ & $\begin{array}{l}585 \text { children aged } 10 \\
\text { years attending } \\
\text { elementary school; } \\
\text { random selection of } \\
\text { schools, consecutive } \\
\text { sampling of children }\end{array}$ & 4 & $\begin{array}{l}\text { Intake } \\
\text { (servings/week) of } \\
\text { SSSD and sweets; } \\
\text { FFQ }\end{array}$ & $\begin{array}{l}\text { Change in BMI z } \\
\text { score } \\
\text { (continuous); self } \\
\text { reported }\end{array}$ & $\begin{array}{l}\text { Adjusted for dietary } \\
\text { intake and change in } \\
\text { dietary intake, SES, } \\
\text { sex, time since baseline }\end{array}$ & $\begin{array}{l}\text { No associations seen between } \\
\text { consumption of SSSD/sweets and } \\
\text { BMI z score }\end{array}$ & 0 \\
\hline
\end{tabular}




\section{Table 7 (continued)}

\begin{tabular}{|c|c|}
\hline $\begin{array}{l}\text { First author } \\
\text { (year), } \\
\text { country, study } \\
\text { name }\end{array}$ & $\begin{array}{l}\text { Population and } \\
\text { recruitment }\end{array}$ \\
\hline $\begin{array}{l}\text { Herbst } \\
(2011),{ }^{87} \\
\text { Germany, } \\
\text { DONALD Study }\end{array}$ & $\begin{array}{l}216 \text { infants aged } 1 \\
\text { year, born to German } \\
\text { citizens; convenience } \\
\text { sampling }\end{array}$ \\
\hline
\end{tabular}

\begin{tabular}{|c|c|c|}
\hline $\begin{array}{c}\text { Follow-up } \\
\text { (years) }\end{array}$ & $\begin{array}{l}\text { Exposure and } \\
\text { assessment } \\
\text { method }\end{array}$ & $\begin{array}{l}\text { Outcome and } \\
\text { assessment } \\
\text { method }\end{array}$ \\
\hline 6 & $\begin{array}{l}\text { Energy intake (\%) } \\
\text { from total added } \\
\text { sugar, added sugar } \\
\text { in beverages and } \\
\text { sweets, added } \\
\text { sugar from other } \\
\text { sources, plus } \\
\text { changes in intake } \\
\text { between } 1-2 \text { years; } \\
3 \text { day diet record }\end{array}$ & $\begin{array}{l}\text { BMI z score and } \\
\text { BF (\%) (both } \\
\text { continuous); } \\
\text { measured }\end{array}$ \\
\hline
\end{tabular}

\section{Covariates and} stratification

Adjusted for birth weight, BMl at birth breastfeeding, dietary beverages and sweets at age 1 year intake, gestational age were negatively associated with BMI (weeks), paternal $\quad \mathrm{z}$ score at age 7 years. BMI $z$ score education, maternal increase per $1 \%$ energy from total overweight, sex $\quad$ added sugar: $\beta-0.116$ (SE 0.057 , $\mathrm{P}=0.04$; from added sugar in beverages and sweets: -0.250 (0.103, $\mathrm{P}=0.02)$. No associations were observed between \% energy intakes from sugars and \% BF

\begin{tabular}{|c|c|c|c|c|c|c|c|}
\hline $\begin{array}{l}\text { Johnson } \\
(2007),{ }^{98} \text { UK, } \\
\text { Avon } \\
\text { Longitudinal } \\
\text { Study of } \\
\text { Parents and } \\
\text { Children, } \\
\text { Children in } \\
\text { Focus }\end{array}$ & $\begin{array}{l}521 \text { children aged } 5 \\
\text { years or } 682 \text { aged } 7 \\
\text { years born in the final } \\
6 \text { month of the AVON } \\
\text { study; consecutive } \\
\text { population sampling } \\
\text { used to obtain AVON } \\
\text { cohort, random } \\
\text { sampling within the } \\
\text { cohort }\end{array}$ & $2 / 4$ & $\begin{array}{l}\text { Intake } \\
\text { (servings/day) of } \\
\text { SSB or FJ at } 5 \text { or } 7 \\
\text { years; } 3 \text { day diet } \\
\text { record }\end{array}$ & $\begin{array}{l}\text { Fat mass index } \\
\left(\mathrm{kg} / \mathrm{m}^{5.8}\right) \ddagger \text { and } \\
\text { change in fat } \\
\text { mass }(\mathrm{kg}) \text { (both } \\
\text { continuous); } \\
\text { measured }\end{array}$ & $\begin{array}{l}\text { Adjusted for baseline } \\
\text { BMI, dietary intake, } \\
\text { height, parental BMI } \\
\text { and SES, sex, TV } \\
\text { viewing }\end{array}$ & $\begin{array}{l}\text { After adjusting for sex and height, fat } \\
\text { mass index } \ddagger \text { at age } 9 \text { years } \\
\text { correlated with SSB intake at } 5 \text { and } \\
7 \text { years (Pearson's correlation } \\
\text { coefficient } P \text { values } 0.06 \text { and } 0.03 \text {, } \\
\text { respectively). In multivariate } \\
\text { regression analysis, fat mass at } 9 \\
\text { years was negatively associated with } \\
\text { FJ intake at } 5 \text { years }(-0.55 \mathrm{~kg} / \text { daily } \\
\text { serving, } 95 \% \mathrm{Cl}-1.08 \text { to }-0.02 \text { ) }\end{array}$ & $\begin{array}{c}+ \\
(\mathrm{SSB}), \\
-(\mathrm{FJ})\end{array}$ \\
\hline
\end{tabular}

Libuda 235 children aged 9-13 5 Energy (MJ) Change in BMI z Adjusted for age, birth 5 year changes in BMI $z$ score and $(2008){ }^{88} \quad$ years, born to German derived from SSB, score weight, energy intake BF (\%) were not related to baseline $\begin{array}{llll}\text { Germany, } & \text { citizens; convenience } & \text { FJ, energetic } & \text { (continuous) and from other sources and intake of SSB, FJ, or combination of } \\ \text { DONALD Study } & \text { sampling } & \text { beverages (SSB } & \% \text { change in BF change in energy intake both. Change in BMI z score was }\end{array}$ DONALD Study sampling $\begin{array}{llll}\begin{array}{l}\text { beverages (SSB } \\ \text { and FJ); and }\end{array} & \text { (continuous); } & \text { change in energy intake } & \text { both. Change in BMI z score was } \\ \text { fromer sources, } & \text { positively associated with concurrent }\end{array}$ $\begin{array}{lll}\text { and FJ); and } & \text { (continuous); } & \text { from other sources, positively associated with concurrent } \\ \text { change in intake; } 3 & \text { measured } & \text { maternal education and change in energetic beverage intake }\end{array}$ day diet record $\quad B M I$, time, years of in girls $(\beta 0.07, P=0.01)$ and with adolescence; stratified concurrent change in $\mathrm{FJ}$ intake in girls by sex $\quad(\beta 0.096 ; P=0.013)$

\begin{tabular}{|c|c|c|c|c|c|}
\hline \multirow[t]{2}{*}{$\begin{array}{l}\text { Lim (2009) }{ }^{97} \\
\text { USA, Detroit } \\
\text { Dental Health } \\
\text { Project }\end{array}$} & \multirow[t]{2}{*}{$\begin{array}{l}365 \text { children aged } 3-5 \\
\text { years from areas in } \\
\text { Detroit with the highest } \\
\text { proportion of low } \\
\text { income households; } \\
\text { random sampling }\end{array}$} & \multirow[t]{2}{*}{2} & $\begin{array}{l}\text { SSB (all, fruit drinks } \\
\text { and SSSD) intake } \\
\text { (ounces/day) and } \\
\text { change in intake } \\
\text { (decrease, } \\
\text { increase, no } \\
\text { change) }\end{array}$ & \multirow[t]{2}{*}{$\begin{array}{l}\text { Change in BMI z } \\
\text { score } \\
\text { (continuous) and } \\
\text { incident } \\
\text { overweight (BMI } \\
\geq 85 \text { th percentile) } \\
\text { (OR); measured }\end{array}$} & \multirow[t]{2}{*}{$\begin{array}{l}\text { Adjusted for baseline } \\
\text { BMI, caregiver's BMI, } \\
\text { SES, total energy } \\
\text { intake }\end{array}$} \\
\hline & & & FFQ & & \\
\hline
\end{tabular}
Odds of becoming overweight increased by $4 \%(95 \% \mathrm{Cl} 1 \%$ to $7 \%$; $\mathrm{P}<0.05)$ per ounce of fruit drink consumed per day at baseline, $4 \%$ $(1 \%$ to $6 \% ; P<0.05)$ per ounce of all SSB consumed per day at baseline, and $4 \%$ per ounce of SSSD consumed per day at baseline, although non-significantly $(95 \% \mathrm{Cl}$ $-1 \%$ to $10 \% ; P>0.05)$. No significant association found between change in beverage intakes and incidence of overweight (data not reported). No significant association found between change in beverage intakes and change in BMI z score

\begin{tabular}{|c|c|c|c|c|c|c|c|}
\hline $\begin{array}{l}\text { Ludwig } \\
(2001),{ }^{95} \text { USA, } \\
\text { Planet Health }\end{array}$ & $\begin{array}{l}548 \text { multiethnic } \\
\text { children aged } 11-12 \\
\text { years participating in } \\
\text { an intervention study } \\
\text { as controls; } \\
\text { convenience sampling } \\
\text { of schools, random } \\
\text { assignment of schools } \\
\text { to intervention/control, } \\
\text { consecutive sampling } \\
\text { of children }\end{array}$ & 1.6 & $\begin{array}{l}\text { SSB intake } \\
\text { (servings/day) and } \\
\text { change in intake } \\
\text { (increase of } 1 \\
\text { serving/day); FFQ }\end{array}$ & $\begin{array}{l}\text { Incident obesity } \\
\text { (BMl and triceps } \\
\text { skinfold } \geq 85 \text { th } \\
\text { percentile) (OR) } \\
\text { and change in } \\
\text { BMI (continuous); } \\
\text { measured }\end{array}$ & $\begin{array}{l}\text { Adjusted for age, } \\
\text { baseline BMI and } \\
\text { triceps skinfold, dietary } \\
\text { intake and change in } \\
\text { dietary intake, ethnicity, } \\
\text { physical activity, school } \\
\text { indicator variables, sex, } \\
\text { total energy intake, TV } \\
\text { viewing, and change in } \\
\text { TV viewing }\end{array}$ & $\begin{array}{l}\text { For each serving of SSB } \\
\text { consumed/day at baseline, BMI } \\
\text { increased by } 0.18 \text { ( } 95 \% \mathrm{Cl} 0.09 \text { to } \\
0.27 ; \mathrm{P}=0.02) \text {, and for each SSB } \\
\text { serve/d increase from baseline, BMI } \\
\text { increased by } 0.24 \text { ( } 0.10 \text { to } 0.39 \text {; } \\
\mathrm{P}=0.03) \text {. Incident obesity was not } \\
\text { associated with baseline SSB intake } \\
(\mathrm{OR} 1.48,95 \% \mathrm{Cl} 0.63 \text { to } 3.47 ; \\
\mathrm{P}=0.27) \text {, but was associated with an } \\
\text { increase in SSB intake, with a } 60 \% \\
\text { higher risk of developing obesity for } \\
\text { each serving/day increase }(95 \% \mathrm{Cl} \\
14-124 \% ; \mathrm{P}=0.02) \text {. }\end{array}$ & + \\
\hline
\end{tabular}




\section{Table 7 (continued)}

\begin{tabular}{|c|c|c|c|c|c|}
\hline $\begin{array}{l}\text { First author } \\
\text { (year), } \\
\text { country, study } \\
\text { name }\end{array}$ & $\begin{array}{l}\text { Population and } \\
\text { recruitment }\end{array}$ & $\begin{array}{l}\text { Follow-up } \\
\text { (years) }\end{array}$ & $\begin{array}{l}\text { Exposure and } \\
\text { assessment } \\
\text { method }\end{array}$ & $\begin{array}{l}\text { Outcome and } \\
\text { assessment } \\
\text { method }\end{array}$ & $\begin{array}{l}\text { Covariates and } \\
\text { stratification }\end{array}$ \\
\hline $\begin{array}{l}\text { Nissinen } \\
(2009)^{82} \\
\text { Finland, } \\
\text { Cardiovascular } \\
\text { Risk in Young } \\
\text { Finns Study }\end{array}$ & $\begin{array}{l}2139 \text { children aged } 3, \\
6,9,12,15, \text { and } 18 \\
\text { years; random } \\
\text { sampling }\end{array}$ & 21 & $\begin{array}{l}\text { Intakes of SSSD or } \\
\text { sweets in childhood } \\
\text { (per } 10 \\
\text { units/month), } \\
\text { increase, decrease, } \\
\text { or no change in } \\
\text { SSSD/sweets } \\
\text { intake from } \\
\text { childhood to } \\
\text { adulthood; } \\
\text { questionnaire }\end{array}$ & $\begin{array}{l}\text { Adult BMI } \\
\text { (continuous) and } \\
\text { adult overweight } \\
\text { status (BMI } \geq 25 \text { ) } \\
\text { (OR); measured }\end{array}$ & $\begin{array}{l}\text { Adjusted for adult } \\
\text { education, age, } \\
\text { overweight status in } \\
\text { childhood, physical } \\
\text { activity, smoking; } \\
\text { stratified by sex }\end{array}$ \\
\hline
\end{tabular}

\begin{tabular}{|c|c|c|c|c|c|}
\hline $\begin{array}{l}\text { Phillips } \\
(2004),{ }^{89} \text { USA, } \\
\text { Massachusetts } \\
\text { Institute of } \\
\text { Technology } \\
\text { Growth and } \\
\text { Development } \\
\text { Study }\end{array}$ & $\begin{array}{l}132 \text { premenarcheal } \\
\text { girls aged } 8-12 \text { years } \\
\text { attending public } \\
\text { schools in } \\
\text { Massachusetts; } \\
\text { convenience sampling }\end{array}$ & About 7 & $\begin{array}{l}\text { Energy intake (\%) } \\
\text { from energy dense } \\
\text { snacks (SSSD, } \\
\text { candy/chocolate, } \\
\text { baked goods, ice } \\
\text { cream), divided into } \\
\text { groups according to } \\
\text { intake level; FFQ }\end{array}$ & $\begin{array}{l}\text { BMI z score and } \\
\text { BF (\%) } 4 \text { years } \\
\text { after onset of } \\
\text { menarche (both } \\
\text { continuous); } \\
\text { measured }\end{array}$ & $\begin{array}{l}\text { Adjusted for age at } \\
\text { menarche, dietary } \\
\text { intake, parental } \\
\text { overweight }\end{array}$ \\
\hline
\end{tabular}

\begin{tabular}{|c|c|c|c|c|c|c|c|}
\hline & & & & & & $(\%)$ & \\
\hline $\begin{array}{l}\text { Skinner } \\
(2001),{ }^{90} \text { USA }\end{array}$ & $\begin{array}{l}72 \text { white children aged } \\
2 \text { years, born to } \\
\text { parents with middle to } \\
\text { high SES; convenience } \\
\text { sampling }\end{array}$ & 4 & $\begin{array}{l}\text { Longitudinal intake } \\
\text { of FJ (ounces/day; } \\
\text { mean across } 7 \text { sets } \\
\text { of measurements); } \\
24 \text { h recall and } 3 \\
\text { day diet record }\end{array}$ & $\begin{array}{l}\text { BMl and } \\
\text { ponderal index } \\
\left(\mathrm{kg} / \mathrm{m}^{3}\right) \text { (both } \\
\text { continuous); } \\
\text { measured }\end{array}$ & $\begin{array}{l}\text { Adjusted for age, } \\
\text { baseline BMI or } \\
\text { ponderal index, } \\
\text { longitudinal total energy } \\
\text { intake, parental BMI, } \\
\text { sex }\end{array}$ & $\begin{array}{l}\text { Longitudinal FJ intake was not } \\
\text { significantly associated with BMI ( } \beta \\
-0.057 ; P=0.099 \text { ), but was negatively } \\
\text { associated with ponderal index ( } \beta \\
-0.065 ; P=0.05 \text { ) }\end{array}$ & $0 /-$ \\
\hline $\begin{array}{l}\text { Stoof (2011), }{ }^{91} \\
\text { Holland, } \\
\text { Amsterdam } \\
\text { Growth and } \\
\text { Health } \\
\text { Longitudinal } \\
\text { Study }\end{array}$ & $\begin{array}{l}238 \text { adolescents aged } \\
13 \text { years, attending } \\
\text { secondary schools of } \\
\text { middle to high SES in } \\
\text { and around } \\
\text { Amsterdam; } \\
\text { convenience sampling }\end{array}$ & $24-30$ & $\begin{array}{l}\text { Intake of SSB } \\
\text { (servings/day); diet } \\
\text { history }\end{array}$ & $\begin{array}{l}\text { BMI, BF (\%) and } \\
\text { trunk fat (\%) (all } \\
\text { continuous); } \\
\text { measured }\end{array}$ & $\begin{array}{l}\text { Adjusted for age, } \\
\text { baseline BMI, } \\
\text { developmental age at } \\
\text { baseline, physical } \\
\text { activity, total energy } \\
\text { intake }\end{array}$ & $\begin{array}{l}\text { For men, each additional daily serving } \\
\text { of } \mathrm{SSB} \text { at age } 13 \text { years was } \\
\text { associated with greater } \mathrm{BF}(\%) \text { in } \\
\text { adulthood }(\beta 1.14,95 \% \mathrm{Cl}(0.04 \text { to } \\
2.23) ; \mathrm{P}=0.04) \text {. In women, each } \\
\text { additional daily serving of } \mathrm{SSB} \text { at } 13 \\
\text { years was associated with greater } \\
\text { trunk fat in adulthood ( } \beta 1.62(0.14 \text { to } \\
3.10) ; \mathrm{P}=0.03) \text {. No relation between } \\
\mathrm{SSB} \text { consumption at age } 13 \text { years } \\
\text { and } \mathrm{BMI} \text { in adulthood found in either } \\
\text { sex }\end{array}$ & + \\
\hline $\begin{array}{l}\text { Striegel-Moore } \\
(2006),{ }^{92} \text { USA, } \\
\text { National Heart, } \\
\text { Lung and } \\
\text { Blood Institute } \\
\text { Growth and } \\
\text { Health Study }\end{array}$ & $\begin{array}{l}2371 \text { non-Hispanic } \\
\text { black and white girls } \\
\text { aged 9-10 years, } \\
\text { attending schools in } \\
\text { Richmond, Hamilton } \\
\text { County, and Maryland, } \\
\text { from families enrolled } \\
\text { in a health } \\
\text { maintenance } \\
\text { organisation in the } \\
\text { Washington, DC area, } \\
\text { and girl scouts in the } \\
\text { Washington, DC area; } \\
\text { convenience sampling }\end{array}$ & 10 & $\begin{array}{l}\text { Intake of SSSD, FJ, } \\
\text { fruit drinks ( } 100 \\
\text { g/day); } 3 \text { day diet } \\
\text { record }\end{array}$ & $\begin{array}{l}\text { Concurrent } \\
\text { change in BMI } \\
\text { (continuous); } \\
\text { measured }\end{array}$ & $\begin{array}{l}\text { Adjusted for ethnicity, } \\
\text { intake of other } \\
\text { beverages, study site } \\
\text { and visit, total energy } \\
\text { intake, within-individual } \\
\text { correlation of repeated } \\
\text { measures }\end{array}$ & $\begin{array}{l}\text { Beverage intake was measured at } \\
\text { baseline and at most annual follow-up } \\
\text { visits (visits } 1-5,7,8 \text {, and } 10 \text { ). } \\
\text { Concurrent change in BMI was } \\
\text { positively associated with intake of } \\
\text { SSSD per } 100 \mathrm{~g} / \text { day ( } \beta 0.011 \text { (SE } \\
0.005 \text { ); } P<0.050 \text { ). BMI was not found } \\
\text { to be associated with intake of } F J \text { or } \\
\text { fruit drinks (both } P \geq 0.05 \text { ) }\end{array}$ & $\begin{array}{c}+ \\
(\mathrm{SSB}) \\
-(\mathrm{FJ})\end{array}$ \\
\hline
\end{tabular}




\section{Table 7 (continued)}

\begin{tabular}{|c|c|c|c|c|c|c|c|}
\hline $\begin{array}{l}\text { First author } \\
\text { (year), } \\
\text { country, study } \\
\text { name }\end{array}$ & $\begin{array}{l}\text { Population and } \\
\text { recruitment }\end{array}$ & $\begin{array}{c}\text { Follow-up } \\
\text { (years) }\end{array}$ & $\begin{array}{l}\text { Exposure and } \\
\text { assessment } \\
\text { method }\end{array}$ & $\begin{array}{l}\text { Outcome and } \\
\text { assessment } \\
\text { method }\end{array}$ & $\begin{array}{l}\text { Covariates and } \\
\text { stratification }\end{array}$ & Findings* & $+/ 0 /-\dagger$ \\
\hline $\begin{array}{l}\text { Vanselow } \\
(2009),{ }^{78} \text { USA, } \\
\text { Project EAT }\end{array}$ & $\begin{array}{l}2294 \text { adolescents aged } \\
11-15 \text { years, attending } \\
31 \text { ethnically and } \\
\text { socioeconomically } \\
\text { diverse schools in } \\
\text { Minneapolis or St Paul; } \\
\text { convenience sampling }\end{array}$ & 5 & $\begin{array}{l}\text { Servings/week of } \\
\text { SSSD, fruit drinks, } \\
\text { orange juice, apple } \\
\text { juice; FFQ }\end{array}$ & $\begin{array}{l}\text { Change in BMI } \\
\text { (continuous); self } \\
\text { reported }\end{array}$ & $\begin{array}{l}\text { Adjusted for age, } \\
\text { physical activity at } \\
\text { baseline and follow-up, } \\
\text { baseline BMI, cohort, } \\
\text { ethnicity, other } \\
\text { beverage intake, SES, } \\
\text { sex, TV viewing at } \\
\text { follow-up }\end{array}$ & $\begin{array}{l}\text { No association found between } \\
\text { consumption of SSSD, fruit drinks, } \\
\text { orange or apple juice at baseline and } \\
\text { BMI at follow-up }\end{array}$ & 0 \\
\hline $\begin{array}{l}\text { Viner }(2006),{ }^{79} \\
\text { UK, } 1970 \\
\text { British Birth } \\
\text { Cohort }\end{array}$ & $\begin{array}{l}4461 \text { adolescents aged } \\
16 \text { years, born in one } \\
\text { week in } 1970 \text { in } \\
\text { England, Northern } \\
\text { Ireland, Scotland, and } \\
\text { Wales; consecutive } \\
\text { sampling }\end{array}$ & 14 & $\begin{array}{l}0,1, \text { or } \geq 2 \text { servings } \\
\text { of SSSD on } \\
\text { previous day; } \\
\text { questionnaire }\end{array}$ & $\begin{array}{l}\text { Change in BMI z } \\
\text { score at age } \\
16-30 \text { years } \\
\text { (continuous); self } \\
\text { reported }\end{array}$ & $\begin{array}{l}\text { Adjusted for baseline } \\
\text { BMI z score, height at } \\
\text { baseline and follow-up, } \\
\text { SES, sex }\end{array}$ & $\begin{array}{l}\text { Compared with people who } \\
\text { consumed no SSSD on the day } \\
\text { before baseline, those who reported } \\
\text { consuming } \geq 2 \text { servings had a } \\
\text { significantly greater change in } \mathrm{BMI} z \\
\text { score over the } 14 \text { year follow-up ( } \beta \\
0.13 \text { (95\% Cl } 0.01 \text { to } 0.26) ; \mathrm{P}<0.04)\end{array}$ & + \\
\hline $\begin{array}{l}\text { Weijs }(2011),{ }^{80} \\
\text { Holland }\end{array}$ & $\begin{array}{l}120 \text { infants aged } 4-13 \\
\text { months; convenience } \\
\text { sampling }\end{array}$ & 8 & $\begin{array}{l}\text { Intake of total sugar } \\
\text { and intake of } \\
\text { beverage sugar ( } \% \\
\text { of total energy, } \\
\text { g/day); } \\
2 \text { day diet record }\end{array}$ & $\begin{array}{l}\text { Overweight } \\
\text { status at age } 8 \\
\text { years }(\geq 1 \\
\text { increased in BMl } \\
\text { z score) }(\mathrm{OR}) ; \\
\text { self reported }\end{array}$ & $\begin{array}{l}\text { Adjusted for animal } \\
\text { protein intake, baseline } \\
\text { age, baseline body } \\
\text { weight, breastfeeding, } \\
\text { SES, sex }\end{array}$ & $\begin{array}{l}\text { In unadjusted analyses, sugar intake } \\
\text { at baseline ( } \% \text { of total energy and } \\
\mathrm{g} / \text { day) and beverage sugar intake at } \\
\text { baseline ( } \mathrm{g} / \text { day) did not differ } \\
\text { between people not overweight and } \\
\text { those overweight at follow-up. } \\
\text { However, beverage sugar intake (as } \\
\% \text { of total energy) differed between } \\
\text { the groups ( } \mathrm{P}=0.04) . \text { For intake of } \\
\text { beverage sugar per } 1 \% \text { of total } \\
\text { energy intake, adjusted OR for } \\
\text { overweight at age } 8 \text { years was } 1.13 \\
\text { (95\% } \mathrm{Cl} 1.03 \text { to } 1.24 \text { ) }\end{array}$ & + \\
\hline $\begin{array}{l}\text { Welsh (2005) }{ }^{96} \\
\text { USA, Pediatric } \\
\text { Nutrition } \\
\text { Surveillance } \\
\text { System and } \\
\text { Missouri } \\
\text { Demonstration } \\
\text { Project }\end{array}$ & $\begin{array}{l}10904 \text { children aged } \\
2-3 \text { years enrolled in } \\
\text { the Special Nutrition } \\
\text { Program for Women, } \\
\text { Infants, and Children in } \\
\text { Missouri; consecutive } \\
\text { sampling }\end{array}$ & 1 & $\begin{array}{l}\text { SSB intake } \\
\text { (servings/day: } 0 \text { to } \\
<1,1 \text { to }<2,2 \text { to }<3 \text {, } \\
\geq 3 \text { ); FFQ }\end{array}$ & $\begin{array}{l}\text { Overweight } \\
\text { status at } \\
\text { follow-up (BMI } \\
\geq 95 \text { th percentile) } \\
\text { (OR); measured }\end{array}$ & $\begin{array}{l}\text { Adjusted for age, birth } \\
\text { weight, dietary intake, } \\
\text { ethnicity, sex, total } \\
\text { energy intake; stratified } \\
\text { by being normal or } \\
\text { under weight at } \\
\text { baseline (BMI <85th } \\
\text { percentile), being at risk } \\
\text { of overweight at } \\
\text { baseline (BMI 85th to } \\
<95 \text { th percentile), or } \\
\text { being overweight at } \\
\text { baseline (BMI } \geq 95 \text { th } \\
\text { percentile) }\end{array}$ & $\begin{array}{l}\text { Children who were at risk for } \\
\text { overweight at baseline and consumed } \\
\geq 1 \mathrm{SSB} / \text { day were } 1.8-2.0 \text { times more } \\
\text { likely to become overweight than } \\
\text { children who consumed }<1 \mathrm{SSB} / \text { day. } \\
\text { Children who were overweight at } \\
\text { baseline and consumed } \geq 1 \mathrm{SSB} / \text { day } \\
\text { were } 1.8-2.1 \text { times as likely to remain } \\
\text { overweight than children who } \\
\text { consumed }<1 \mathrm{SSB} / \text { day. There was a } \\
\text { positive but non-significant relation } \\
\text { between SSB consumption and } \\
\text { development of overweight in children } \\
\text { who were normal or under weight at } \\
\text { baseline }\end{array}$ & + \\
\hline $\begin{array}{l}\text { Williams } \\
(2008),{ }^{93} \text { USA, } \\
\text { Healthy Start } \\
\text { Project }\end{array}$ & $\begin{array}{l}519 \text { children aged } 3-4 \\
\text { years, attending } 1 \text { of } 9 \\
\text { selected preschools in } \\
\text { upstate New York; } \\
\text { convenience sampling }\end{array}$ & 4 & $\begin{array}{l}\text { Sucrose intake } \\
\text { (g/day); direct } \\
\text { observation and } 24 \\
\text { h recall }\end{array}$ & $\begin{array}{l}\text { BMI at } 1 \text { year } \\
\text { follow-up } \\
\text { (continuous); } \\
\text { measured }\end{array}$ & $\begin{array}{l}\text { Adjusted for dietary } \\
\text { intake at baseline and } \\
\text { follow-up, baseline BMI, } \\
\text { ethnicity, sex, total } \\
\text { energy intake }\end{array}$ & $\begin{array}{l}\text { Sucrose intake at baseline was } \\
\text { inversely associated with } \mathrm{BMI} \text { at } \\
\text { follow-up }(\beta-0.10, P<0.05)\end{array}$ & - \\
\hline
\end{tabular}

ANOVA=analysis of variance; $B F=$ body fat; $F F Q=f o o d$ frequency questionnaire; $F J=100 \%$ fruit juice; $O R=0 d d s$ ratio; $S D=$ standard deviation; $S E=$ standard error; SES=socioeconomic status; SSSD=sugar sweetened soft drinks; SSB=sugar sweetened beverages (including cordials, energy drinks, fruit drinks, iced tea, soft drinks); TV=television; WC waist circumference.

*Most adjusted results are reported unless otherwise stated.

†Higher sugar intake positively associated with weight gain (+), not associated with weight gain (0), and negatively associated with weight gain (-). $\ddagger$ Fat mass index is usually defined as body fat mass $(\mathrm{kg}) / \mathrm{height}\left(\mathrm{m}^{2}\right)$; in Johnson et al ${ }^{98}$ it is $\mathrm{kg} / \mathrm{m}^{5.8}$. 


\section{Figures}

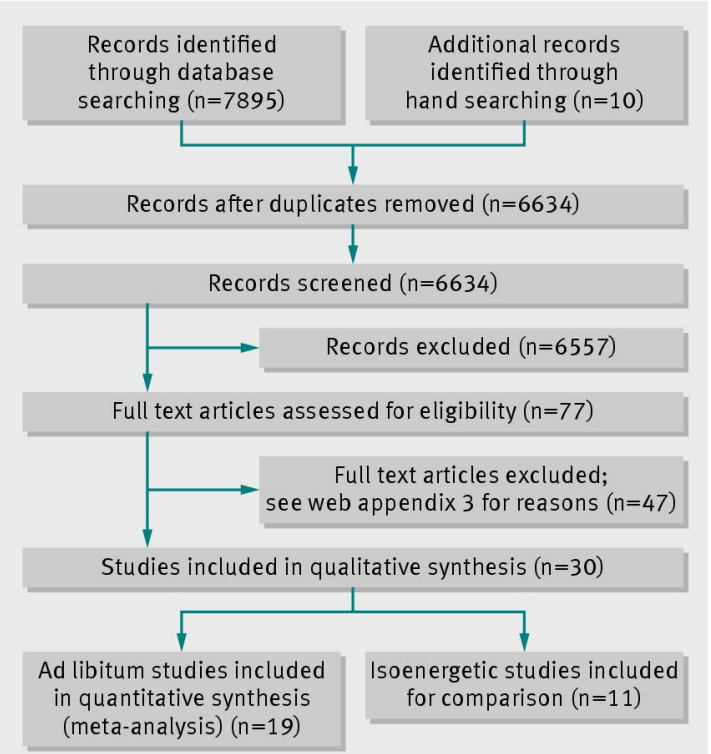

Fig 1 PRISMA flow diagram for randomised controlled trials

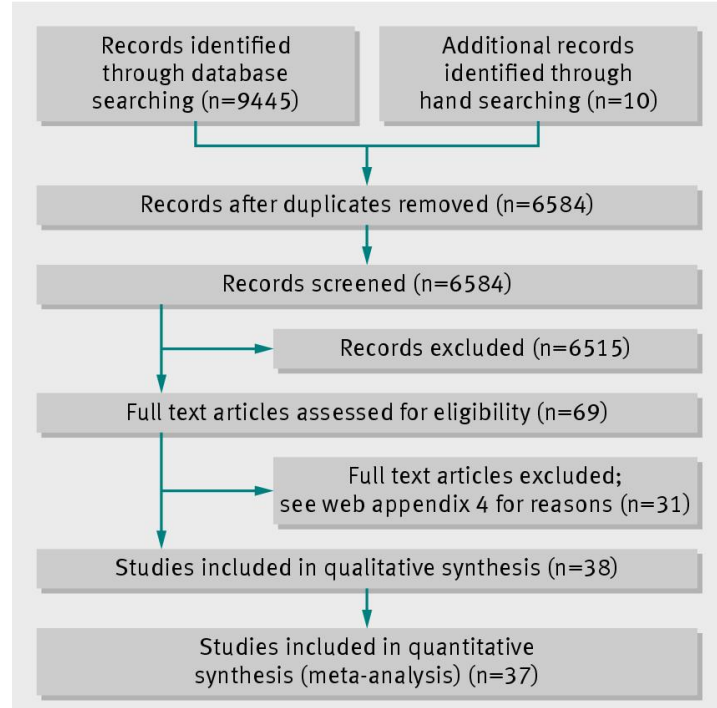

Fig 2 PRISMA flow diagram for cohort studies 


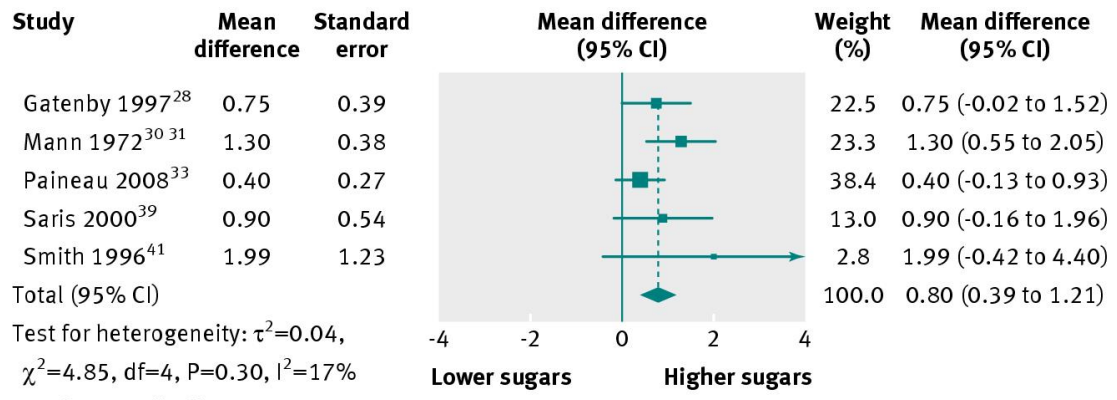

Test for overall effect: $z=3.85$, $P<0.001$

Fig 3 Effect of reducing intake of free sugars on measures of body fatness in adults. Pooled effects for difference in body weight $(\mathrm{kg})$ shown for studies comparing reduced intakes (lower sugars) with usual or increased intakes (higher sugars). Overall effect shows increased body weight after intervention in the higher sugars groups. Data are expressed as weighted mean difference ( $95 \%$ confidence interval), using generic inverse variance models with random effects

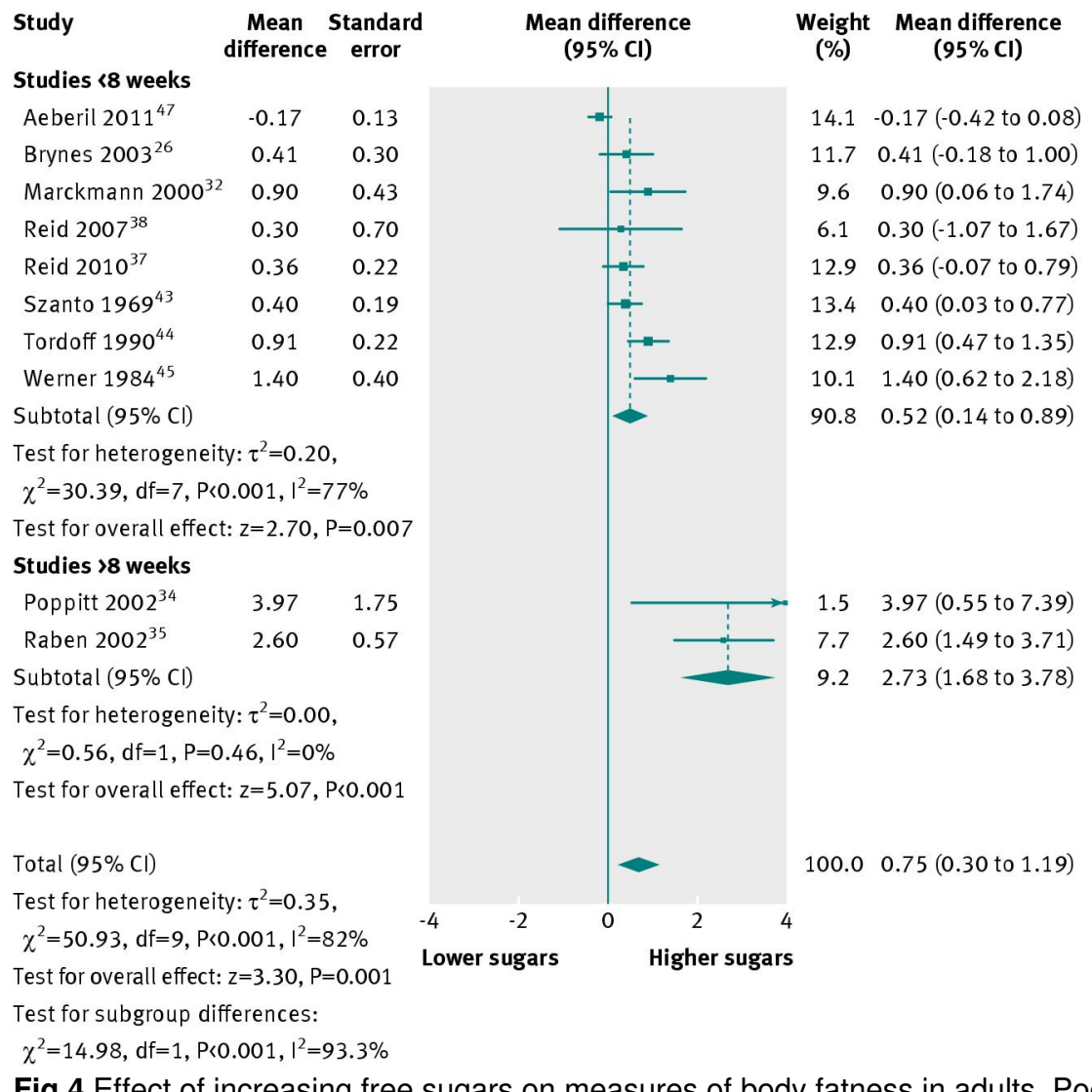

Fig 4 Effect of increasing free sugars on measures of body fatness in adults. Pooled effects for difference in body weight (kg) shown for studies comparing increased intake (higher sugars) with usual intake (lower sugars). Overall effect shows increased body weight after intervention in the higher sugars groups. Data are expressed as weighted mean difference (95\% confidence interval), using generic inverse variance models with random effects 


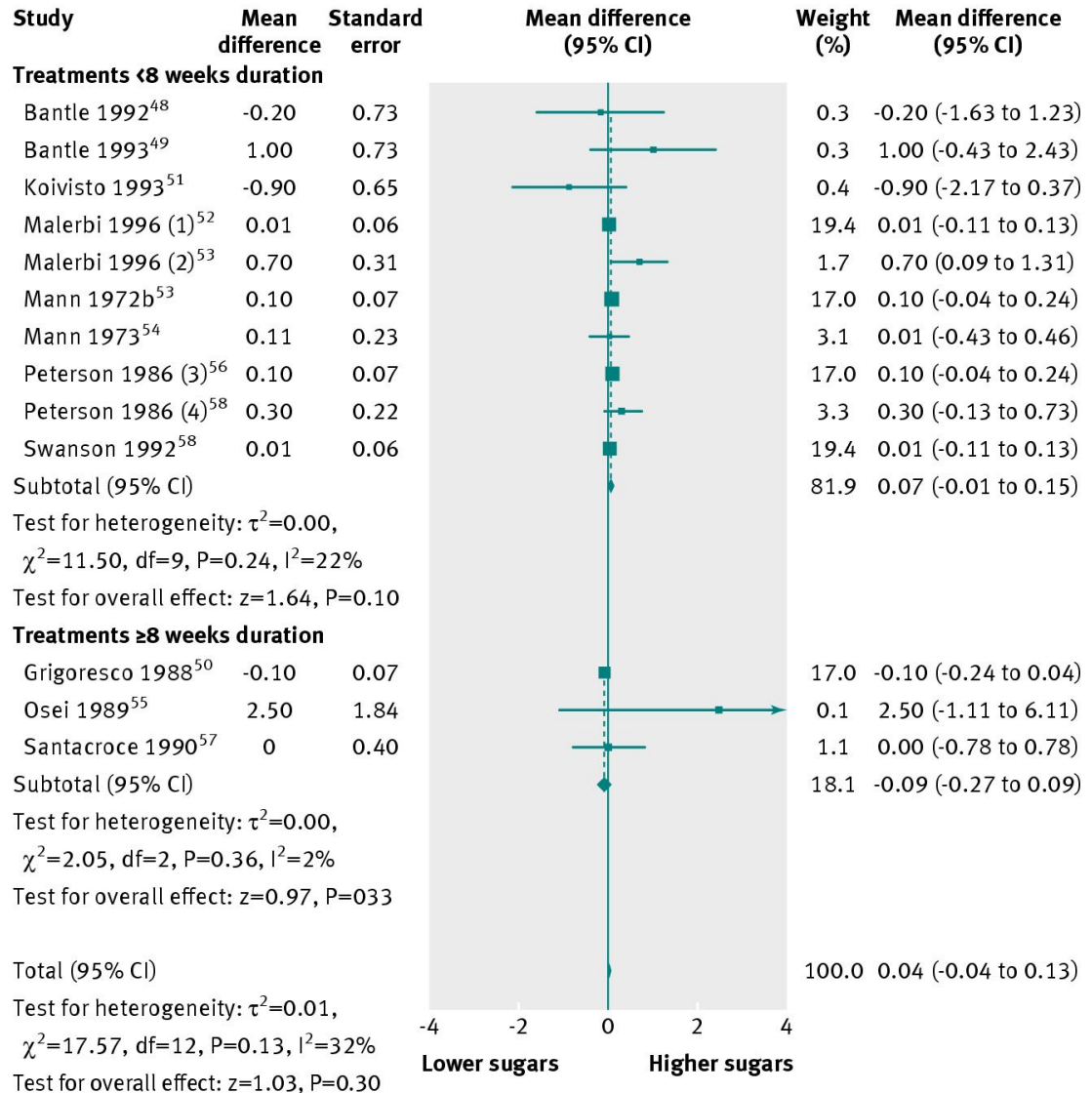

Test for subgroup differences:

$\chi^{2}=2.42, \mathrm{df}=1, P=0.12,\left.\right|^{2}=58.6 \%$

(1) Fructose $v$ starch, (2) Sucrose $v$ starch, (3) Patients with type 1 diabetes, (4) Patients with type 2 diabetes

Fig 5 Isoenergetic exchanges of free sugars with other carbohydrates or other macronutrient sources. Pooled effects for difference in body weight $(\mathrm{kg})$ for studies comparing isoenergetic exchange of free sugars (higher sugars) with other carbohydrates (lower sugars). Data are expressed as weighted mean difference (95\% confidence interval), using generic inverse variance models with random effects

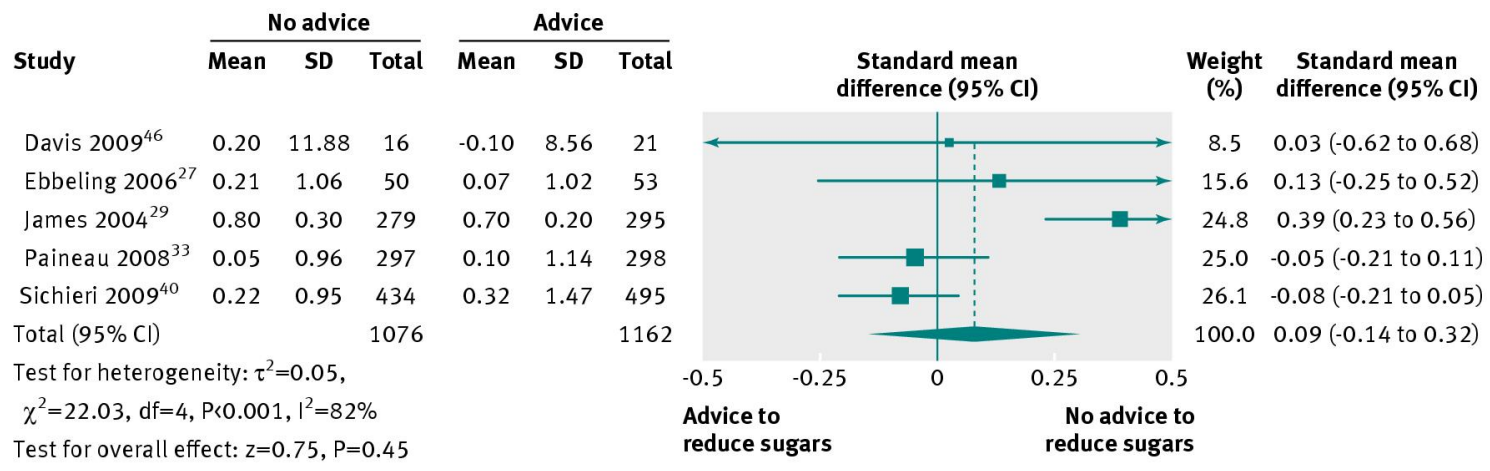

Fig 6 Effect of reducing free sugars on measures of body fatness in children. Pooled effects for standardised mean difference in body mass index for studies comparing advice to reduce intake of free sugars with no advice regarding free sugars. Data are expressed as weighted, standardised mean difference (95\% confidence interval), using generic inverse variance models with random effects 


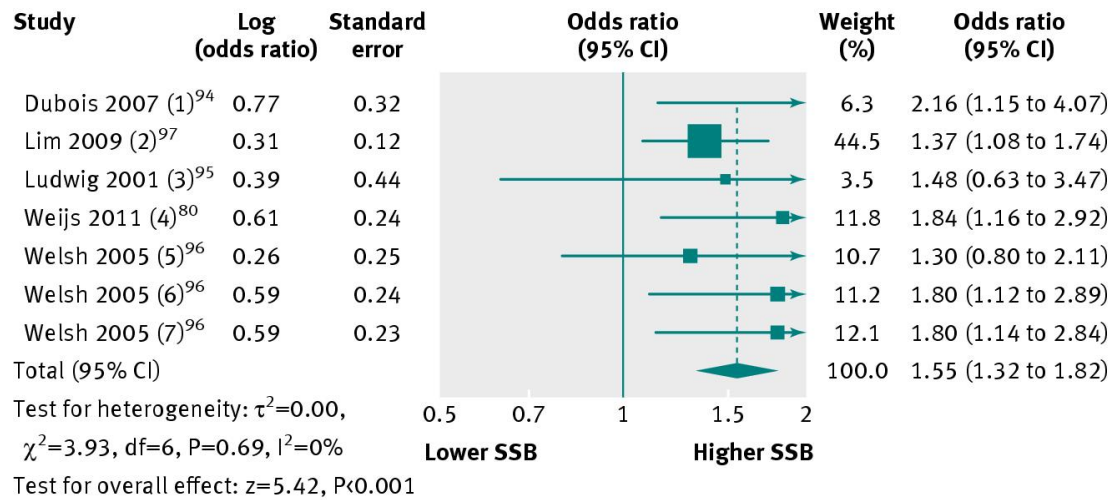

(1) $O R$ for incident obesity in frequent versus infrequent consumers of SSB between meals

(2) OR for incident overweight per daily serve SSB $(80 z)$

(3) OR for incident obesity per daily serve SSB

(4) OR for incident overweight per approximate daily serve SSB (5\% energy from beverage sugar)

(5) OR for incident overweight in normal weight children who consumed $>1$ serve/d SSB versus $<1$ serve $S S B / d$

(6) OR for remaining overweight in overweight children who consumed $>1$ serve/d SSB versus 41 serve $S S B / d$

(7) OR for incident overweight in children at risk of overweight who consumed $>1$ serve/d SSB versus $\$ 1$ serve SSB/d

Fig 7 Association between free sugars intakes and measures of body fatness in children. Pooled estimates for odd ratios for incident overweight or obesity in children consuming one or more servings of sugar sweetened beverages per day at baseline compared with children who consumed none or very little at baseline. Overall estimate shows higher odds of overweight or obesity at follow-up in those who consumed one or more servings of sugar sweetened beverages at baseline. Data are expressed as odds ratio (95\% confidence interval), using generic inverse variance models with random effects

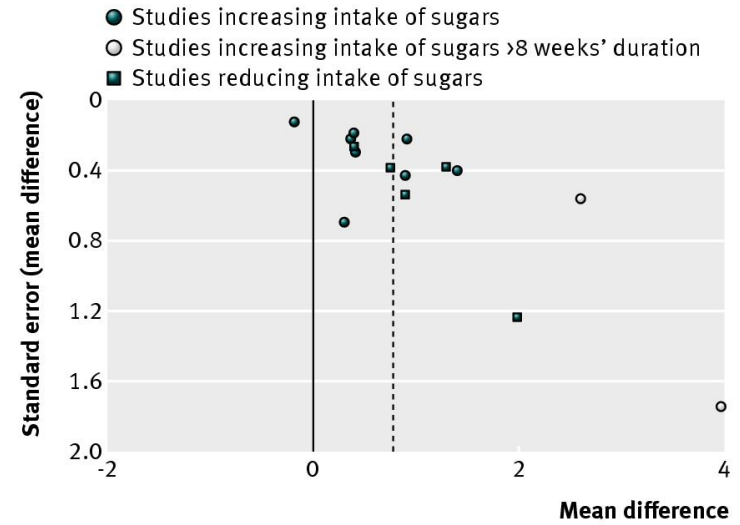

Fig 8 Funnel plot of randomised ad libitum trials in adults 